Article

\title{
Evolution and Antibacterial Evaluation of 8-Hydroxy-cycloberberine Derivatives as a Novel Family of Antibacterial Agents Against MRSA
}

\author{
Yuan-Shuai Yang ${ }^{\dagger}$, Wei Wei ${ }^{\dagger}$, Xin-Xin Hu, Sheng Tang, Jing Pang ${ }^{\circledR}$, Xue-Fu You, Tian-Yun Fan *, \\ Yan-Xiang Wang *(D) and Dan-Qing Song \\ Beijing Key Laboratory of Antimicrobial Agents, Institute of Medicinal Biotechnology, Chinese Academy of \\ Medical Sciences and Peking Union Medical College, Beijing 100050, China; yangmarshal88@163.com (Y.-S.Y.); \\ weiwei082695@163.com (W.W.); huxinxin1985@163.com (X.-X.H.); tang13874204108@163.com (S.T.); \\ pangjing.pangjing@163.com (J.P.); 13311123098@163.com (X.-F.Y.); songdanqingsdq@hotmail.com (D.-Q.S.) \\ * Correspondence: fty1668@163.com (T.-Y.F.); wangyanxiang@imb.pumc.edu.cn (Y.-X.W.); \\ Tel.: +86-10-6316-5284 (T.-Y.F.); +86-10-6303-3012 (Y.-X.W.) \\ + These authors made equal contribution to this work.
}

Received: 14 February 2019; Accepted: 8 March 2019; Published: 11 March 2019

check for updates

\begin{abstract}
Twenty-five new derivatives of 8-hydroxycycloberberine (1) were synthesized and evaluated for their activities against Gram-positive bacteria, taking 1 as the lead. Part of them displayed satisfactory antibacterial activities against methicillin-susceptible Staphylococcus aureus (MSSA) and methicillin-resistant Staphylococcus aureus (MRSA), as well as vancomycin-intermediate Staphylococcus aureus (VISA). Especially, compound 15a displayed an excellent anti-MRSA activity with MICs (minimum inhibitory concentrations) of $0.25-0.5 \mu \mathrm{g} / \mathrm{mL}$, better than that of 1 . It also displayed high stability in liver microsomes and whole blood, and the $\mathrm{LD}_{50}$ value of over 65.6 $\mathrm{mg} \cdot \mathrm{kg}^{-1}$ in mice via intravenous route, suggesting a good druglike feature. The mode of action showed that 15a could effectively suppress topo IV-mediated decatenation activity at the concentration of $7.5 \mu \mathrm{g} / \mathrm{mL}$, through binding a different active pocket of bacterial topo IV from quinolones. Taken together, the derivatives of $\mathbf{1}$ constituted a promising kind of anti-MRSA agents with a unique chemical scaffold and a specific biological mechanism, and compound 15a has been chosen for the next investigation.
\end{abstract}

Keywords: cycloberberine; anti-MRSA; structure-activity relationship; topoisomerase IV

\section{Introduction}

Methicillin-resistant Staphylococcus aureus (MRSA), classified as serious threat pathogen, has become a main cause of hospital and community-acquired infections across the world [1-4]. In the US alone, at least two million illnesses and 23,000 deaths are caused by multidrug-resistant bacterial infections every year according to data released by the Centers for Disease Control and Prevention (CDC) [1]. Thereinto, around 19,000 deaths and 360,000 hospitalizations resulted from infections of MRSA along with \$3-4 billion in healthcare costs [5]. Vancomycin, linezolid and daptomycin have been used as the last resort for MRSA infections in the clinic. Unfortunately, vancomycin-intermediate $S$. aureus (VISA), heteroresistant VISA (hVISA), vancomycin-resistant $S$. aureus (VRSA), linezolid-resistant S. aureus and daptomycin-resistant $S$. aureus have been successively reported [6-10]. Especially, MRSA/VISA have been listed as global priority pathogens of antibiotic-resistant bacteria released by the World Health Organization (WHO) on Feb 27th 2017 [11], and the treatment of MRSA/VISA infections has become severe concerns across the world. Therefore, great efforts must be made to 
explore alternative agents witH-Novel structure scaffold or mechanism of action for the treatment of invasive life-threatening infections arising from MRSA/VISA.

In the past several years, our team has been committed to the discovery and development of novel antibacterial agents against multidrug-resistant pathogens, witH-Novel chemical entities and biological mode of action [12,13]. We first discovered that the cycloberberine (CBBR, Figure 1), generated from berberine (BBR) in our lab [14], was a special molecular scaffold against both methicillin-susceptible S. aureus (MSSA) and MRSA, as well as VISA $[15,16]$. The primary structure-activity relationships (SAR) demonstrated that introducing a suitable mono-substituent at the 8- or 13-position of CBBR could significantly enhance the antibacterial activity against MSSA/MRSA $[15,16]$, though CBBR itself had no bactericidal activity at all, as shown in Figure 1. The top compound 8-hydroxycycloberberine (1, Figure 1) displayed a promising effect against the tested strains such as MRSA with MIC values of $0.5->64 \mu \mathrm{g} / \mathrm{mL}$, which is much higher than that of levofloxacin (Lev) widely used in the clinic.

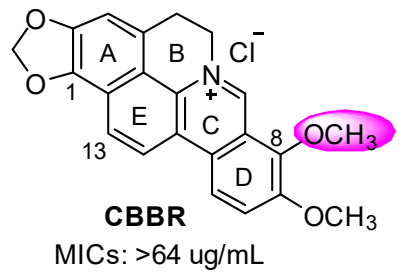

Figure 1. Structures of CBBR and $\mathbf{1}$ as well as modification strategies.

Interestingly, compared with CBBR possessing a 8- $\mathrm{OCH}_{3}$ group, compound $\mathbf{1}$ with 8-OH showed a greatly significant improvement in activity against both MSSA and MRSA, indicating that the $8-\mathrm{OH}$ function might play a critical role in enhancing the antibacterial effects. The unique chemical scaffold and biological activity of $\mathbf{1}$ encouraged us to continue a new round of SAR of its derivatives, aiming at developing these compounds into a new class of drug candidates against MRSA. Therefore, in the present study, as depicted in Figure 1, taking compound $\mathbf{1}$ as the lead, the 8-OH in CBBR was retained, and various substituents were respectively attached on the 13-position, by which a series of new 1 derivatives were designed, synthesized and then evaluated for their antibacterial effect against MSSA and MRSA. Additionally, the stability in liver microsomes and whole blood, toxicity in vivo as well as the bactericidal mechanism studies of the representative compounds were carried out as well.

\section{Results and Discussion}

\subsection{Chemistry}

The synthetic routes to all twenty-five target compounds are displayed in Schemes 1 and 2 respectively. As shown in Scheme 1, palmatine was selectively reduced to dihydropalmatine (2) in $89 \%$ yield using $\mathrm{NaBH}_{4}$ as a reducing agent in the presence of $5 \% \mathrm{NaOH} / \mathrm{K}_{2} \mathrm{CO}_{3}$ using a previous procedure [14]. Compound 2 was then reacted with $40 \%$ glyoxal in refluxing $\mathrm{HOAc} / \mathrm{CH}_{3} \mathrm{CN}$ to give the intermediate 13-acetaldehyde palmatine (3), to which $\mathrm{CH}_{3} \mathrm{OH} / \mathrm{HCl}(2 / 1$ by vol.) was added directly to complete the cyclization reaction and the desired product cyclopalmatine (4) was obtained in an overall yield of $62 \%$. Then, compound 4 was heated at $195-210^{\circ} \mathrm{C}$ under vacuum $(20-30 \mathrm{mmHg})$ to get the key intermediate 5 . Finally, product $\mathbf{6}$ was acquired with a combined $90 \%$ conversion via acidification of compound 5 with concentrated $\mathrm{HCl} / \mathrm{EtOH}$ (5/95 by vol.) by a classic keto-enol tautomerism.

As described in Scheme 2, CBBR was prepared from BBR using a previously reported procedure [14]. Compound 8 was prepared via demethylenation of CBBR with benzene-1,3,5-triol and $60 \% \mathrm{H}_{2} \mathrm{SO}_{4}$ in a yield of $62 \%$. The demethylation of 8 yielded intermediate 9 , which was converted quickly to 1,2,8-trihydroxyl 10 in the presence of concentrated $\mathrm{HCl} / \mathrm{EtOH}(5 / 95)$ in a combined 39\% yield. Dihydrocycloberberine (11) was prepared in $83 \%$ yield via reduction of $\mathrm{CBBR}$ witH-NaBH 4 as a 
reducing agent in $\mathrm{CH}_{3} \mathrm{OH}$ in the presence of $\mathrm{K}_{2} \mathrm{CO}_{3}$ [15]. The compounds in series 12 were generated in $24-47 \%$ yields from 11 and diverse substituted benzyl bromides at reflux temperature.

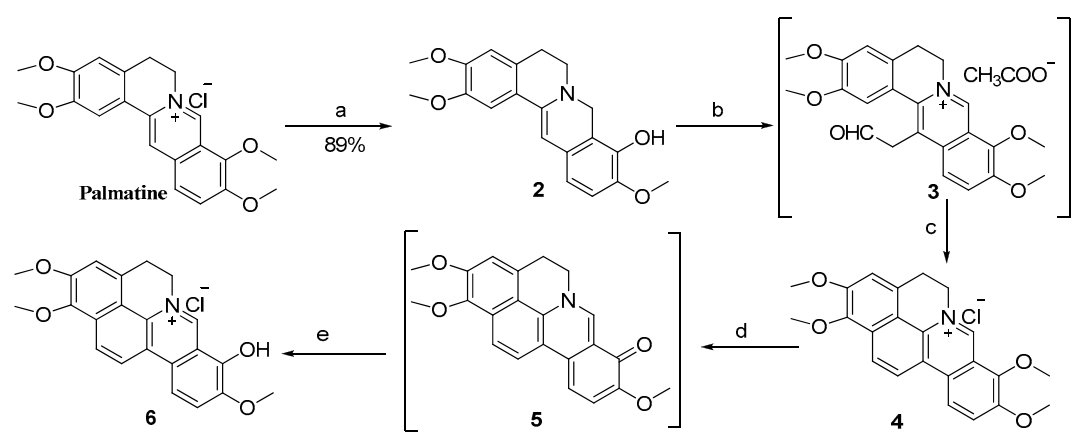

Scheme 1. Reagents and conditions: (a) $\mathrm{NaBH}_{4}, 5 \% \mathrm{NaOH} / \mathrm{K}_{2} \mathrm{CO}_{3}, \mathrm{CH}_{3} \mathrm{OH}$, room temperature, 3 h; (b) $40 \%$ glyoxal, $\mathrm{HOAc} / \mathrm{CH}_{3} \mathrm{CN}$, reflux, 6 h; (c) $\mathrm{CH}_{3} \mathrm{OH} / \mathrm{HCl}$ (2/1 by vol.), room temperature, $24 \mathrm{~h}$, $62 \%$ (over two steps); (d) 20-30 mmHg, 195-210 ${ }^{\circ} \mathrm{C}, 40 \mathrm{~min}$; (e) $\mathrm{HCl} / \mathrm{EtOH}$ (5/95 by vol.), 90\% (over two steps).

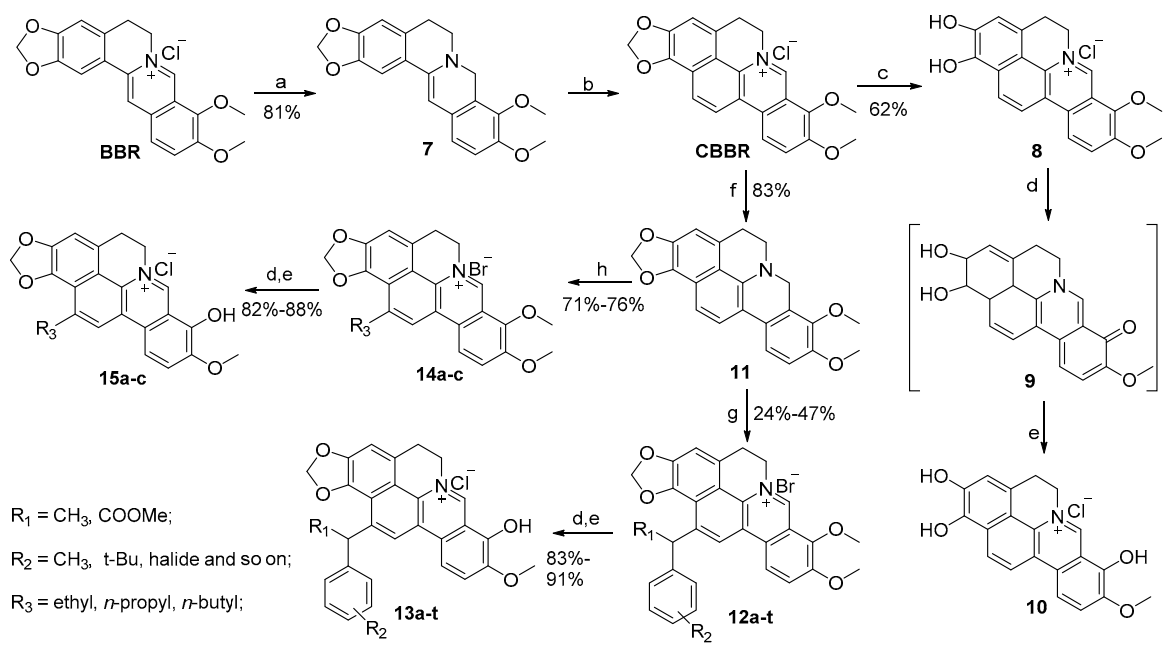

Scheme 2. Reagents and conditions: (a) $\mathrm{NaBH}_{4}, 5 \% \mathrm{NaOH}, \mathrm{K}_{2} \mathrm{CO}_{3}, \mathrm{CH}_{3} \mathrm{OH}$, r.t., 3 h; (b) (i) $40 \%$ glyoxal, $\mathrm{HOAc}, \mathrm{CH}_{3} \mathrm{CN}$, reflux, $6 \mathrm{~h}$; (ii) $\mathrm{CH}_{3} \mathrm{OH} / \mathrm{HCl}$ (2/1 by vol.), room temperature, $24 \mathrm{~h}, 67 \%$ (over two steps); (c) benzene-1,3,5-triol, 60\% $\mathrm{H}_{2} \mathrm{SO}_{4}$; (d) 20-30 mmHg, 195-210 ${ }^{\circ} \mathrm{C}$, $40 \mathrm{~min}$; (e) $\mathrm{HCl} / \mathrm{EtOH}(5 / 95$ by vol.), $39 \%$ (over two steps); (f) $\mathrm{NaBH}_{4}, \mathrm{~K}_{2} \mathrm{CO}_{3}, \mathrm{CH}_{3} \mathrm{OH}$, room temperature, $12 \mathrm{~h}$; (g) substituted benzyl bromide, $\mathrm{K}_{2} \mathrm{CO}_{3}$ (2.0 eq.), $\mathrm{CH}_{3} \mathrm{CN}$, reflux, 3-24 h; (h) aliphatic aldehyde, $\mathrm{HOAc}, 80 \% \mathrm{EtOH}$, reflux, $8 \mathrm{~h}$.

Similarly, compounds $\mathbf{1 2 a}-\mathbf{t}$ were heated at $195-210^{\circ} \mathrm{C}$ for $40 \mathrm{~min}$ under vacuum $(20-30 \mathrm{mmHg})$ and acidified using concentrated $\mathrm{HCl} / \mathrm{EtOH}(5 / 95)$ to produce the target compounds 13a-t in good yields. Meanwhile, the products in series 14 were obtained in good yields from 11 and diverse aliphatic aldehydes in $\mathrm{HOAc}$ and $80 \% \mathrm{EtOH}$ at reflux temperature. The products $\mathbf{1 5 a}-\mathbf{c}$ were generated from 14a-c using a similar synthetic method as for compounds $\mathbf{1 3} \mathbf{a}-\mathbf{t}$. All the desired products were purified with flash column chromatography on silica gel using $\mathrm{CH}_{2} \mathrm{Cl}_{2}$ and $\mathrm{CH}_{3} \mathrm{OH}$ as eluents or washed with 95\% EtOH. The ${ }^{1} \mathrm{H}-\mathrm{NMR},{ }^{13} \mathrm{C}-\mathrm{NMR}$ and HRMS data of compound 15a is provided in Supplementary Materials. 


\subsection{Pharmacological Evaluation}

\subsubsection{SAR for Anti-Bacterial Activity}

SAR study for antibacterial activity against drug-susceptible Gram-positive bacteria was initially carried out, taking Lev and compound 1 as reference drugs. The chemical structures of 25 target compounds and their MIC values against a panel of drug-susceptible strains [17], including MSSA, methicillin-susceptible S. epidermidis (MSSE), S. saprophyticus (S. s) and S. hominis (S. h), were summarized in Table 1. Bacteria strains used in this study were from the ATCC collection and clinical isolates in Chinese hospitals. The influence of the methylenedioxy ring was explored first, and compounds 6 and 10 were created and tested. As shown in Table 1, both of them lost the antimicrobial activities partially or completely, suggesting that methylenedioxy ring might be essential for the activity against Gram-positive strains.

Table 1. Antimicrobial activities of the target compounds against drug-susceptible Gram-positive strains (MIC $\left.(\mu \mathrm{g} / \mathrm{mL})^{\mathrm{a}}\right)$.

\begin{tabular}{|c|c|c|c|c|c|c|c|c|c|}
\hline \multirow{2}{*}{ Code } & \multirow{2}{*}{$\mathbf{R}_{1} / \mathbf{R}_{2}$} & \multirow{2}{*}{$\mathbf{R}_{3}$} & \multicolumn{3}{|c|}{ MSSA $^{c}$} & \multicolumn{2}{|c|}{$\operatorname{MSSE}^{c}$} & \multirow{2}{*}{$\begin{array}{l}\text { S.s } \\
\text { ATCC } \\
15305\end{array}$} & \multirow{2}{*}{$\begin{array}{l}\text { S.h } \\
\text { ATCC } \\
35982 \\
\end{array}$} \\
\hline & & & $\begin{array}{l}\text { ATCC } \\
29213 \\
\end{array}$ & $15^{b}$ & $16-1^{b}$ & $\begin{array}{l}\text { ATCC } \\
12228\end{array}$ & $16-5^{b}$ & & \\
\hline CBBR & - & - & $>64$ & $>64$ & $>64$ & $>64$ & $>64$ & $>64$ & $>64$ \\
\hline 1 & - & - & 0.5 & 4 & 1 & 0.5 & 0.5 & $>64$ & 1 \\
\hline 6 & - & - & $>64$ & $>64$ & $>64$ & $>64$ & $>64$ & $>64$ & $>64$ \\
\hline 10 & - & - & 32 & 16 & 32 & 8 & 16 & 32 & 32 \\
\hline $13 a$ & $\mathrm{H}$ & $\mathrm{H}$ & 8 & 16 & 8 & 16 & 8 & 8 & 8 \\
\hline $13 b$ & $\mathrm{H}$ & $p$-F & $>64$ & $>64$ & $>64$ & $>64$ & $>64$ & $>64$ & $>64$ \\
\hline $13 c$ & $\mathrm{H}$ & $2^{\prime}, 4^{\prime}-(\mathrm{F})_{2}$ & 8 & 8 & 8 & 8 & 8 & 16 & 8 \\
\hline $13 d$ & $\mathrm{H}$ & $2^{\prime}, 6^{\prime}-(\mathrm{F})_{2}$ & $>64$ & $>64$ & $>64$ & $>64$ & $>64$ & $>64$ & $>64$ \\
\hline $13 \mathrm{e}$ & $\mathrm{H}$ & $p-\mathrm{Cl}$ & 8 & 8 & 4 & 8 & 4 & 16 & 8 \\
\hline $13 \mathrm{f}$ & $\mathrm{H}$ & $p-\mathrm{Br}$ & 4 & 4 & 2 & 4 & 2 & 4 & 4 \\
\hline $13 g$ & $\mathrm{H}$ & $o-\mathrm{CH}_{3}$ & $>64$ & $>64$ & $>64$ & $>64$ & $>64$ & $>64$ & $>64$ \\
\hline $13 \mathrm{~h}$ & $\mathrm{H}$ & $m-\mathrm{CH}_{3}$ & 4 & 4 & 4 & 4 & 2 & 16 & 8 \\
\hline $13 \mathbf{i}$ & $\mathrm{H}$ & $p-\mathrm{CH}_{3}$ & 8 & 8 & 4 & 8 & 4 & 16 & 4 \\
\hline $13 j$ & $\mathrm{H}$ & $3^{\prime}, 5^{\prime}-\left(\mathrm{CH}_{3}\right)_{2}$ & 32 & 32 & 32 & 32 & 16 & 64 & 32 \\
\hline $13 k$ & $\mathrm{H}$ & $p$-tBu & 32 & 32 & 16 & 16 & 8 & 32 & 32 \\
\hline 131 & $\mathrm{H}$ & $p-\mathrm{OCF}_{3}$ & 32 & 32 & 32 & 32 & 32 & 64 & 64 \\
\hline $13 \mathrm{~m}$ & $\mathrm{H}$ & $o-\mathrm{CN}$ & $>64$ & $>64$ & $>64$ & $>64$ & $>64$ & $>64$ & $>64$ \\
\hline $13 n$ & $\mathrm{H}$ & $m-\mathrm{CN}$ & $>64$ & $>64$ & $>64$ & 16 & 32 & $>64$ & 64 \\
\hline 130 & $\mathrm{H}$ & $p-\mathrm{CN}$ & 8 & 4 & 8 & 8 & 16 & 16 & 16 \\
\hline $13 p$ & $\mathrm{H}$ & $o-\mathrm{NO}_{2}$ & 8 & 8 & 4 & 8 & 4 & 16 & 8 \\
\hline $13 q$ & $\mathrm{H}$ & $m-\mathrm{NO}_{2}$ & $>64$ & $>64$ & 64 & 64 & 32 & $>64$ & 64 \\
\hline $13 r$ & $\mathrm{H}$ & $p-\mathrm{NO}_{2}$ & 16 & 8 & 16 & 4 & 4 & 32 & 8 \\
\hline $13 \mathrm{~s}$ & $\mathrm{CH}_{3}$ & $\mathrm{H}$ & 16 & 8 & 16 & 32 & 16 & 64 & 32 \\
\hline $13 t$ & $\mathrm{CO}_{2} \mathrm{CH}_{3}$ & $\mathrm{H}$ & 64 & 64 & $>64$ & 64 & 32 & $>64$ & 64 \\
\hline $15 a$ & $\mathrm{CH}_{2} \mathrm{CH}_{3}$ & - & 0.5 & 0.5 & 0.5 & 0.5 & 0.25 & 1 & 0.5 \\
\hline $15 b$ & $\left(\mathrm{CH}_{2}\right)_{2} \mathrm{CH}_{3}$ & - & 2 & 2 & 2 & 2 & 1 & 8 & 2 \\
\hline $15 c$ & $\left(\mathrm{CH}_{2}\right)_{3} \mathrm{CH}_{3}$ & - & 8 & 4 & 4 & 8 & 8 & 16 & 4 \\
\hline Lev & & & 0.125 & 0.125 & 0.25 & 0.126 & 0.125 & 1 & 0.125 \\
\hline
\end{tabular}

${ }^{a}$ MIC $(\mu \mathrm{g} / \mathrm{mL})$, minimum inhibitory concentration; ${ }^{b}$ Strains isolated from patients in China. ${ }^{\mathrm{c}}$ Methicillinsusceptible S. aureus (MSSA), methicillin-susceptible S. epidermidis (MSSE), S. saprophyticus (S. s) and S. hominis (S. h).

Then, we moved SAR analysis to the influence of substituent at the 13-position in compound 1. Our previous SAR results on CBBR indicated that the introduction of a 13-benzyl motif was beneficial for the activity [16], therefore, various benzyl moieties with electron-donating and electron-withdrawing groups on the benzene ring were respectively introduced into position 13, and 20 new analogs 13a-t were constructed and tested. As described in Table 1, compound 13a with a 13-benzyl displayed moderate antimicrobial activity with MICs of $8-16 \mu \mathrm{g} / \mathrm{mL}$, while the 
compounds $\mathbf{1 3 b}-\mathbf{d}$ with fluoro atoms as an isostere of the hydrogen atom lost their potency to varying degrees. However, the compounds $\mathbf{1 3 e}$ and $\mathbf{1 3 f}$ with $p$-chloro or $p$-bromo groups showed preferable antimicrobial activities with MIC values of $2-8 \mu \mathrm{g} / \mathrm{mL}$. Compounds $\mathbf{1 3 h}$ and $\mathbf{1 3 i}$ bearing $m$-methyl and p-methyl gave potent activities with MICs of 2-16 $\mu \mathrm{g} / \mathrm{mL}$, less than that of lead 1 . Next, compounds 130 and $13 p$ with $p-\mathrm{CN}$ and $o-\mathrm{NO}_{2}$ respectively displayed moderate antimicrobial activities with most MIC values in the 4-16 $\mu \mathrm{g} / \mathrm{mL}$ range, while other compounds with electron-withdrawing groups showed partially or completely diminished antimicrobial activities.

Furthermore, a methyl or methyloxycarbonyl group was introduced to the $\alpha$-C atom of ring $\mathrm{E}$ to generate 13s and 13t, respectively, and both of them showed decreased activity to different degrees. Finally, an ethyl, n-propyl or n-butyl were respectively introduced at the 13-position of 1, whereby three new analogs 15a-c were prepared and investigated. All of them exhibited good activities against the tested strains with MIC values of $0.25-16 \mu \mathrm{g} / \mathrm{mL}$, and compound 15a showed especially potent activities, with MIC values of $0.25-1.0 \mu \mathrm{g} / \mathrm{mL}$, superior or similar to those of the lead compound 1. The results thus indicate that introducing a small-sized substituent at the 13-position might enhance the activity.

All target compounds were then measured for their antibacterial activities against drug-resistant organisms, such as MRSA/VISA and methicillin-resistant S. epidermidis strains (MRSE). As listed in Table 2, their potencies against MRSE/MRSA/VISA strains were basically consistent with those against drug-susceptible ones. Most of compounds showed potential anti-MRSA and anti-VISA effects with MIC values ranging from 1 to $64 \mu \mathrm{g} / \mathrm{mL}$. Compounds 13e-f, 13h-i, 13o-p and 15a-c displayed promising effects, with MIC values ranging from 0.25 to $8 \mu \mathrm{g} / \mathrm{mL}$. Especially, compound 15a displayed an excellent effect against MRSA and VISA with MIC values of $0.25-0.5 \mu \mathrm{g} / \mathrm{mL}$, better than that of $\mathbf{1}$, and then it was selected as the representative compound for the next investigation.

Table 2. Antibacterial activities of the target compounds against drug-resistant Gram-positive strains $(\mathrm{MIC}(\mu \mathrm{g} / \mathrm{mL}))$.

\begin{tabular}{|c|c|c|c|c|c|c|c|c|c|c|}
\hline \multirow{2}{*}{ Code } & \multicolumn{6}{|c|}{ MRSA } & \multicolumn{2}{|c|}{ VISA } & \multicolumn{2}{|c|}{ MRSE } \\
\hline & $13-18$ & $13-23$ & $16-34$ & $\begin{array}{l}\text { ATCC } \\
43300\end{array}$ & 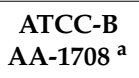 & $\begin{array}{c}\text { ATCC } \\
\text {-BAA-976 b }\end{array}$ & $\begin{array}{l}\text { ATCC } \\
700698\end{array}$ & $\begin{array}{l}\text { ATCC } \\
700699\end{array}$ & $13-3$ & $16-5$ \\
\hline CBBR & $>64$ & $>64$ & $>64$ & $>64$ & $>64$ & $>64$ & $>64$ & $>64$ & $>64$ & $>64$ \\
\hline 1 & 1 & 1 & 0.5 & 0.5 & 0.5 & 1 & 1 & 0.5 & $>64$ & 0.5 \\
\hline 6 & $>64$ & $>64$ & $>64$ & $>64$ & $>64$ & $>64$ & $>64$ & $>64$ & $>64$ & $>64$ \\
\hline 10 & 32 & 64 & 16 & 32 & 16 & 64 & 32 & 32 & 32 & 16 \\
\hline $13 a$ & 16 & 16 & 8 & 16 & 8 & 16 & 8 & 8 & 8 & 16 \\
\hline $13 b$ & $>64$ & $>64$ & $>64$ & $>64$ & $>64$ & $>64$ & $>64$ & $>64$ & $>64$ & $>64$ \\
\hline $13 c$ & 16 & 8 & 8 & 8 & 4 & 8 & 8 & 8 & 8 & 8 \\
\hline $13 d$ & $>64$ & $>64$ & $>64$ & $>64$ & $>64$ & $>64$ & $>64$ & $>64$ & $>64$ & 32 \\
\hline $13 e$ & 8 & 8 & 4 & 8 & 8 & 4 & 4 & 8 & 64 & 4 \\
\hline $13 f$ & 4 & 4 & 4 & 4 & 1 & 2 & 2 & 1 & 16 & 2 \\
\hline $13 \mathrm{~g}$ & $>64$ & $>64$ & $>64$ & $>64$ & $>64$ & $>64$ & $>64$ & $>64$ & 64 & 64 \\
\hline $13 \mathrm{~h}$ & 8 & 8 & 4 & 8 & 4 & 8 & 4 & 4 & 4 & 4 \\
\hline $13 i$ & 8 & 8 & 8 & 16 & 2 & 4 & 4 & 4 & 2 & 2 \\
\hline $13 \mathbf{j}$ & 32 & 32 & 16 & 32 & 16 & 32 & 32 & 32 & 16 & 16 \\
\hline $13 k$ & 16 & 32 & 16 & 32 & 8 & 16 & 32 & 32 & 8 & 8 \\
\hline 131 & 32 & 32 & 32 & 64 & 32 & 64 & 64 & 32 & 32 & 32 \\
\hline $13 \mathrm{~m}$ & $>64$ & $>64$ & $>64$ & $>64$ & $>64$ & $>64$ & $>64$ & $>64$ & $>64$ & $>64$ \\
\hline $13 n$ & $>64$ & $>64$ & $>64$ & $>64$ & $>64$ & $>64$ & $>64$ & $>64$ & 64 & 32 \\
\hline 130 & 8 & 8 & 8 & 4 & 8 & 16 & 4 & 8 & 16 & 8 \\
\hline $13 p$ & 16 & 8 & 4 & 8 & 4 & 8 & 8 & 4 & 32 & 8 \\
\hline $13 q$ & $>64$ & $>64$ & $>64$ & $>64$ & $>64$ & 64 & $>64$ & 64 & 64 & 32 \\
\hline $13 r$ & 32 & 8 & 8 & 64 & 4 & 32 & 4 & 4 & $>64$ & 16 \\
\hline $13 \mathrm{~s}$ & 16 & 8 & 16 & 16 & 16 & 32 & 32 & 32 & 32 & 32 \\
\hline $13 t$ & 64 & 64 & $>64$ & 64 & 64 & 64 & 64 & 64 & 64 & 32 \\
\hline $15 a$ & 2 & 0.5 & 0.25 & 0.5 & 0.25 & 0.5 & 0.5 & 0.25 & 1 & 0.25 \\
\hline $15 b$ & 4 & 4 & 2 & 4 & 2 & 2 & 4 & 2 & 4 & 2 \\
\hline $15 c$ & 4 & 8 & 8 & 4 & 8 & 4 & 4 & 4 & 16 & 8 \\
\hline Lev & 32 & 64 & 64 & 32 & 16 & 0.125 & 32 & 8 & 32 & 8 \\
\hline
\end{tabular}




\subsubsection{Time-kill Curve Study of $\mathbf{1 5 a}$}

To further confirm the antibacterial activities of this kind of compounds, the time-kill curve assay of compound 15a for MRSA strain isolated from Chinese patients was carried out subsequently with DMSO as a negative control. As shown in Figure 2, distinct reductions of the viable cell counts were observed after $4 \mathrm{~h}$ exposure of the bacteria to $15 \mathrm{a}$ at concentrations of $2 \times$ and $8 \times \mathrm{MIC}$. Especially, it exhibited significant time-dependent action and the maximum reduction in viable counts was over $6 \log _{10} \mathrm{CFU} / \mathrm{mL}$ in $12 \mathrm{~h}$ for the $8 \times \mathrm{MIC}$, therefore, it was determined that $15 \mathrm{a}$ was a marginal bactericide [18] at the concentration of $8 \times$ MIC.

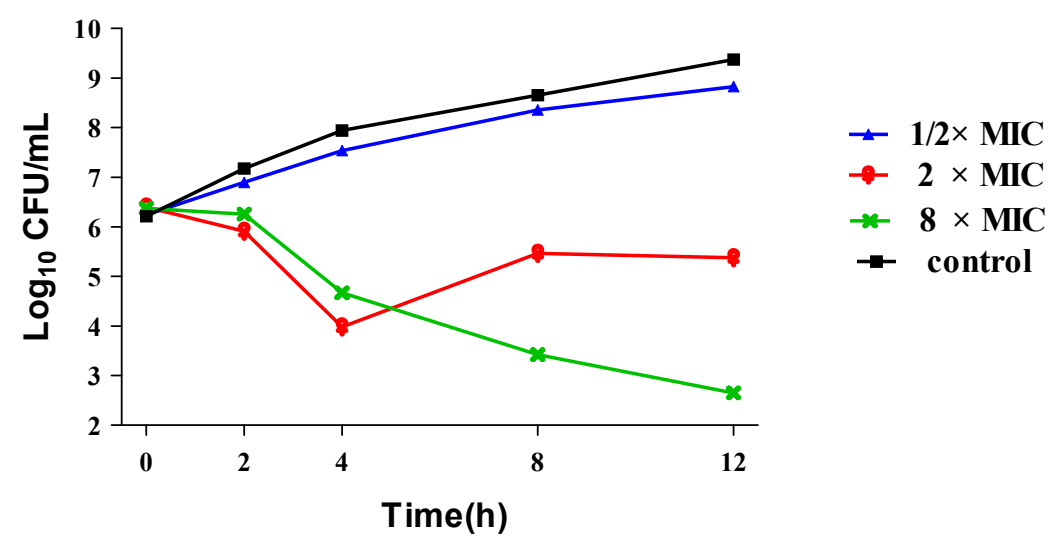

Figure 2. Time-kill curve assay of compound 15a over a $12 \mathrm{~h}$ incubation period at $37^{\circ} \mathrm{C}$ against MRSA 18-4 $(\mathrm{MIC}=0.5 \mu \mathrm{g} / \mathrm{mL})$. Samples were taken at 2, 4, 8 and $12 \mathrm{~h}$ to determine viable bacterial numbers.

\subsubsection{Evaluation of Metabolic Stability and Acute Toxicity Assay of Compound 15a}

The metabolic stability of compound 15a in liver microsomes was conducted in human and rat as well as mouse with the clinical reagent testosterone (Tes) as reference. As depicted in Table 3, compared to Tes, compound 15a showed an obviously longer half-life $\left(\mathrm{T}_{1 / 2}\right)$ and residual ratio, as well as lower microsomal intrinsic clearance in all three species. Especially, the $T_{1 / 2}$ of compound 15a was over $105 \mathrm{~min}$ and the remaining ratio was still $70.6 \%$ after $60 \mathrm{~min}$ in human liver microsomes, indicating a good characteristic of metabolic stability.

Table 3. Metabolic stability of tested compound in human, rat and mouse liver microsomes a

\begin{tabular}{ccccc}
\hline Code & Species & $\mathbf{T}_{\mathbf{1 / 2}} \mathbf{( m i n )}$ & CL Int $(\mathbf{m i c})(\boldsymbol{\mu L} / \mathbf{m i n} / \mathbf{m g})$ & Remaining Ratio (\%) $(\mathbf{T}=\mathbf{6 0} \mathbf{m i n})$ \\
\hline \multirow{3}{*}{ 15a } & Human & 105.3 & 13.2 & 70.6 \\
& Rat & 50.9 & 27.3 & 47.9 \\
& Mouse & 18.9 & 73.4 & 10.4 \\
\hline \multirow{2}{*}{ Tes } & Human & 12.9 & 107.2 & 3.9 \\
& Rat & 0.6 & 2349.8 & 0 \\
& Mouse & 5.5 & 253.9 & 0 \\
\hline
\end{tabular}

${ }^{\mathrm{a}} \mathrm{T}_{1 / 2}=$ half-life. $C L_{\text {int (mic) }}=$ microsomal intrinsic clearance. Liver weight: $20 \mathrm{~g} / \mathrm{kg}$ for humans.

Next, a stability assay of compound 15a was carried out in whole blood in vitro, taking enalapril (Ems) $[15,16]$ as the positive control. As indicated in Table 4, as expected, compound 15a gave an exciting stability profile and the remaining ratio was still over $85.4 \%$ after $24 \mathrm{~h}$ in blood, while Ems was completely decomposed within three hours. The results suggest that 15a might possess an ideal in vivo metabolic stability. 
Table 4. Metabolic stability of 15a in whole blood.

\begin{tabular}{ccccccc}
\hline Time (h) & $\mathbf{0}$ & $\mathbf{0 . 5}$ & $\mathbf{1}$ & $\mathbf{3}$ & $\mathbf{7}$ & $\mathbf{2 4}$ \\
\hline 15a $\operatorname{Rr}(\%)$ & 100 & 98.9 & 98.0 & 95.8 & 93.1 & 85.4 \\
Ems $\operatorname{Rr}(\%)$ & 100 & 37.5 & 9.1 & 0 & 0 & 0 \\
\hline \multicolumn{7}{c}{$\operatorname{Rr}=$ Remaining ratio. }
\end{tabular}

Then, acute toxicity test on compound 15a was performed in Kunming mice through intravenous route. The results indicated that compound 15a gave a half-lethal dose $\left(\mathrm{LD}_{50}\right)$ value of $65.6 \mathrm{mg} \cdot \mathrm{kg}^{-1}$, suggesting a good safety profile.

\subsubsection{Preliminary Mechanism of Compound 15a}

Taking into account the planar rigid structure similarity between $\mathbf{1 5 a}$ and quinolones, we initially examined its effects on gyrase and topoisomerase (topo) IV activities of $S$. aureus by gyrase-mediated supercoiling of relaxed DNA assay and topo IV-mediated decatenation of kinetoplast DNA (kDNA) assay $[19,20]$, respectively. As shown in Figure 3, topo IV-mediated decatenation activity was significantly inhibited in a concentration-dependent manner after treatment of $\mathbf{1 5 a}$. It could partially inhibit topo IV activity at the concentration of $7.5 \mu \mathrm{g} / \mathrm{mL}$ (lane 5), and block almost completely the decatenation reaction at the concentration of $15 \mu \mathrm{g} / \mathrm{mL}$ (lane 7). However, inhibition activity on gyrase-mediated supercoiling was not distinctly observed after treatment with 15a at even upped to $100 \mu \mathrm{g} / \mathrm{mL}$. These results indicated that $\mathbf{1 5 a}$ could effectively suppress the topo IV-mediated decatenation activity, but a different mode of action from quinolones.

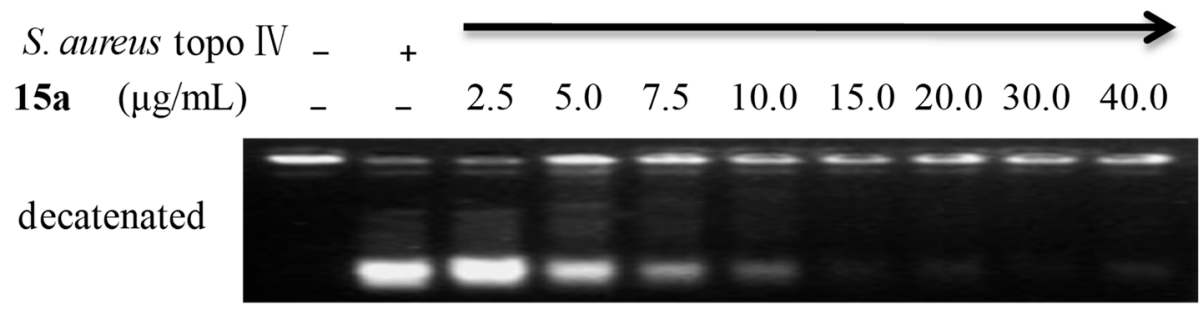

Figure 3. Inhibition of $S$. aureus topo IV. In all panels, enzyme and 15a are absent (-) in lane 1, enzyme present $(+)$ and 15a absent in lane 2, and enzyme (arrow) and 15a present in lanes 3-10 with different concentration. Decatenation activity of topo IV was partially blocked by 15a (lanes 4, 5, 6) and completely blocked by $\mathbf{1 5 a}$ (lanes $7,8,9,10$ ).

\subsubsection{Molecular Docking Study of Key Compound 15a}

It was reported that topo IV enzyme of Gram-positive bacteria possesses at least two active pockets, one is the well-known quinolone-binding cavity and the other is kibdelomycin-binding site [21-23]. In view of the good activity of compound 15a against quinolone-resistant MRSA or VISA, we performed molecular docking between the topo IV binding site of kibdelomycin and compound 15a interactions using Discovery Studio 4.5 software (Edition 4.5; BIOVIA: San Diego, CA, USA, 2015) $[17,24]$. As expected, compound 15a fit well in the active hydrophobic pocket of the binding site (Figure 4A, brown area). One conventional hydrogen bond with GLU53, two attractive charges formed by nitrogen ions with ASP76 and GLU53, van der Waals forces and hydrophobic interactions (Figure 4B) contributed together to the strong interactions. The results suggested that 15a might bind to the kibdelomycin-pocket site on topo IV, a different mode of action from the quinolones widely used in the clinic. 


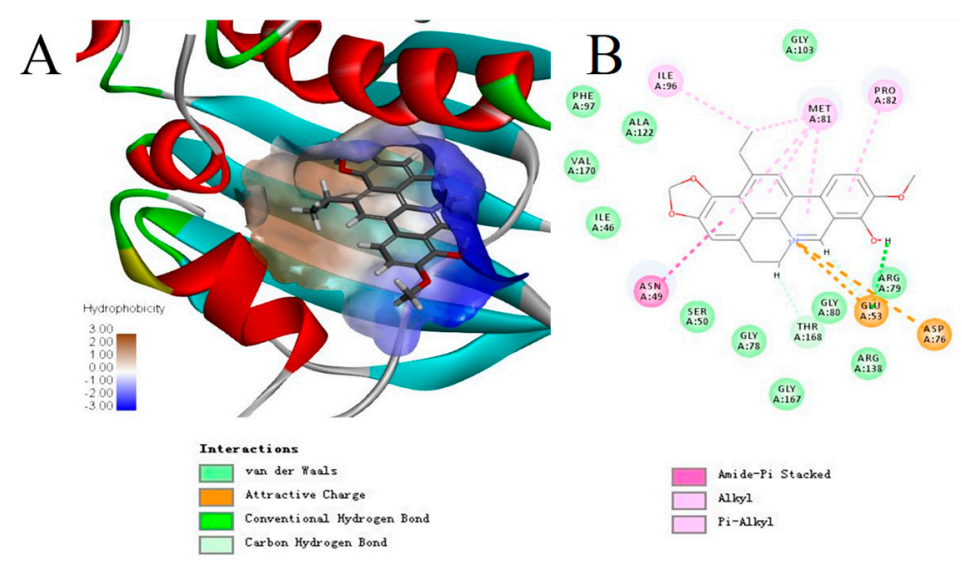

Figure 4. (A) Solid surface map of the interaction pocket with compound 15a. Red, blue, and white colored regions correspond to negatively charged, positively charged, and neutral areas, respectively. (B) Binding modes within the receptor S. aureus topo IV active pocket. These figures were produced using the Discovery Studio 4.5 software. The receptor structure is shown in surface form. Key bonds are indicated by dashed lines between the atoms involved, and the colors of key bonds and residues are shown according to the interaction mode (van der Waals, light green; attractive charge, orange; hydrogen bond, green; carbon hydrogen bond, celadon; amide- $\pi$ stacked, amaranth; alkyl and $\pi$-alkyl, mauve pink).

\section{Experimental Section}

\subsection{Apparatus, Materials, and Analysis Reagents}

Melting points (m.p.) were obtained with a CXM-300 melting point apparatus (Shanghai Changfang Optical Instrument Co., Ltd., Shanghai, China) and are uncorrected. The ${ }^{1} \mathrm{H}-\mathrm{NMR}$ spectra was recorded on an Inova 500 or $600 \mathrm{MHz}$ spectrometer (Varian, San Francisco, CA, USA) and ${ }^{13} \mathrm{C}-\mathrm{NMR}$ on an Avance III 400, 500 or 600 spectrometer (Bruker, Zürich, Switzerland), with $\mathrm{Me}_{4} \mathrm{Si}$ as the internal standard. High-resolution mass spectra (HRMS-ESI) data was recorded on an Autospec UItima-TOF mass spectrometer (Micromass UK Ltd., Manchester, UK). Flash chromatography (particle size $0.038 \mathrm{~mm}$ ) was performed on a CombiflashRf 200 system (Teledyne, Lincoln, NE, USA).

\subsection{Chemistry}

\subsubsection{Synthesis of 1,2-Dimethoxy-8-hydroxy-9-methoxycycloberberine Chloride (6)}

Palmatine $(7.7 \mathrm{~g}, 20 \mathrm{mmol})$ and $\mathrm{K}_{2} \mathrm{CO}_{3}(8.3 \mathrm{~g}, 60 \mathrm{mmol})$ were dissolved in $\mathrm{CH}_{3} \mathrm{OH}(250 \mathrm{~mL})$, and then $5 \% \mathrm{NaOH}(10 \mathrm{~mL})$ solution containing $\mathrm{NaBH}_{4}(0.83 \mathrm{~g}, 22 \mathrm{mmol})$ was added dropwise. The reaction mixture was stirred at room temperature for $3 \mathrm{~h}$. After the reaction was complete, the precipitated solid was filtered, washed with distilled water $(100 \mathrm{~mL})$ and $80 \% \mathrm{EtOH}(100 \mathrm{~mL})$ to give yellow green solid 2. Intermediate $2(5.6 \mathrm{~g}, 16 \mathrm{mmol})$ was then reacted with $40 \%$ glyoxal $(3 \mathrm{~mL})$ in a stirred solvent mixture of $\mathrm{CH}_{3} \mathrm{CN}(160 \mathrm{~mL})$ and HOAc $(40 \mathrm{~mL})$, which was refluxed for $6 \mathrm{~h}$ to prepare compound 3. The solvent was evaporated under vacuum, and $2 \mathrm{~N} \mathrm{HCl} / \mathrm{CH}_{3} \mathrm{OH}(100 \mathrm{~mL})$ was added to the residue. The reaction mixture was stirred at room temperature for $24 \mathrm{~h}$, then evaporated under vacuum and recrystallized from $95 \% \mathrm{EtOH}$ to obtain scarlet solid 4; Yield: $62 \%$, m.p.: $180-182{ }^{\circ} \mathrm{C} .{ }^{1} \mathrm{H}-$ NMR (DMSO- $\left.d_{6}\right) \delta 10.15(\mathrm{~s}, 1 \mathrm{H}), 8.87(\mathrm{~d}, J=9.2 \mathrm{~Hz}, 1 \mathrm{H}), 8.83(\mathrm{~d}, J=9.2 \mathrm{~Hz}, 1 \mathrm{H}), 8.40(\mathrm{~d}, J=9.2 \mathrm{~Hz}, 1 \mathrm{H})$, $8.27(\mathrm{~d}, J=9.2 \mathrm{~Hz}, 1 \mathrm{H}), 7.70(\mathrm{~s}, 1 \mathrm{H}), 5.26(\mathrm{t}, J=6.8 \mathrm{~Hz}, 2 \mathrm{H}), 4.15(\mathrm{~s}, 3 \mathrm{H}), 4.09(\mathrm{~s}, 3 \mathrm{H}), 4.03(\mathrm{~s}, 3 \mathrm{H}), 3.94(\mathrm{~s}$, $3 \mathrm{H}), 3.65(\mathrm{t}, J=6.8 \mathrm{~Hz}, 2 \mathrm{H})$. ESI-MS m/z: 376.15 . Then, $4(3.7 \mathrm{~g}, 9.1 \mathrm{mmol})$ was heated at $195-210{ }^{\circ} \mathrm{C}$ in a dry oven under vacuum (20-30 $\mathrm{mmHg}$ ) for $40 \mathrm{~min}$. After completion of the reaction, the crude material 5 was obtained, which was used without further purification. Next $\mathbf{5}$ was acidified with concentrated $\mathrm{HCl} / \mathrm{EtOH}$ (5:95 by vol.) for $10 \mathrm{~min}$. Then the mixture was evaporated under vacuum and purified with flash column chromatography on silica gel using a $\mathrm{CH}_{2} \mathrm{Cl}_{2}$ and $\mathrm{CH}_{3} \mathrm{OH}$ gradient as 
eluent to obtain the red solid compound 6; yield: $90 \%$; m.p.: $176-178{ }^{\circ} \mathrm{C} ;{ }^{1} \mathrm{H}-\mathrm{NMR}\left(\mathrm{DMSO}-d_{6}\right) \delta 10.07$ $(\mathrm{s}, 1 \mathrm{H}), 8.78(\mathrm{~d}, J=9.6 \mathrm{~Hz}, 1 \mathrm{H}), 8.40-8.32(\mathrm{~m}, 2 \mathrm{H}), 8.06(\mathrm{~d}, J=8.4 \mathrm{~Hz}, 1 \mathrm{H}), 7.67(\mathrm{~s}, 1 \mathrm{H}), 5.18(\mathrm{t}, J=6.6 \mathrm{~Hz}$, 2H), $4.04(\mathrm{~s}, 6 \mathrm{H}), 3.95(\mathrm{~s}, 3 \mathrm{H}), 3.62(\mathrm{t}, J=6.6 \mathrm{~Hz}, 2 \mathrm{H}) ;{ }^{13} \mathrm{C}-\mathrm{NMR}\left(\mathrm{DMSO}-d_{6}\right) \delta 151.0,146.9,146.1,141.3$, 128.4, 128.0 (2), 127.4, 127.3, 123.8, 123.7, 121.8, 121.0, 116.0, 115.8, 114.5, 112.6, 61.2, 56.8, 56.6, 54.9, 26.3; HRMS: calcd for $\mathrm{C}_{22} \mathrm{H}_{20} \mathrm{NO}_{4} \mathrm{Cl}[\mathrm{M}-\mathrm{Cl}]^{+}:$362.1387, found: 362.1390 .

\subsubsection{Synthesis of 1,2,8-Trihydroxy-9-methoxycycloberberine Chloride (10)}

CBBR (3.95 g, $10 \mathrm{mmol})$ and phloroglucin $(5.0 \mathrm{~g}, 40 \mathrm{mmol})$ were added into $60 \% \mathrm{H}_{2} \mathrm{SO}_{4}(20 \mathrm{~mL})$, and the reaction mixture was stirred at $90{ }^{\circ} \mathrm{C}$ for $10 \mathrm{~h}$. Then the mixture was cooled, poured into saturated sodium chloride solution $(10 \mathrm{~mL})$ and filtered. The residue was washed with water and redissolved in $1 \mathrm{~N} \mathrm{NaOH}(60 \mathrm{~mL})$. After that, $2 \mathrm{~N} \mathrm{HCl}(60 \mathrm{~mL})$ was added and the mixture filtered. The residue was purified with flash column chromatography on silica gel using $\mathrm{CH}_{2} \mathrm{Cl}_{2}$ and $\mathrm{CH}_{3} \mathrm{OH}$ to obtain the intermediate 8 in $62 \%$ yield. Next 8 was heated at $195-210{ }^{\circ} \mathrm{C}$ in a dry oven under vacuum (20-30 $\mathrm{mmHg}$ ) for $40 \mathrm{~min}$ to create the crude material 9, which was acidified in concentrated $\mathrm{HCl} / \mathrm{EtOH}$ (5:95 by vol.) for $10 \mathrm{~min}$. Then the mixture was filtered and the residue was washed with water, $\mathrm{CH}_{2} \mathrm{Cl}_{2}$ and EtOH to afford the title compound 10 as a black-purple solid; yield: 39\%; m.p: 191-193 ${ }^{\circ} \mathrm{C} ;{ }^{1} \mathrm{H}-\mathrm{NMR}\left(\mathrm{DMSO}-d_{6}\right) \delta 10.30(\mathrm{~s}, 1 \mathrm{H}), 10.00(\mathrm{~s}, 1 \mathrm{H}), 9.55(\mathrm{~s}, 1 \mathrm{H}), 8.67(\mathrm{~d}, \mathrm{~J}=9.6 \mathrm{~Hz}, 1 \mathrm{H})$, 8.44-8.35 (m, 2H), $8.08(\mathrm{~d}, J=9.0 \mathrm{~Hz}, 1 \mathrm{H}), 7.29(\mathrm{~s}, 1 \mathrm{H}), 5.11(\mathrm{t}, J=6.6 \mathrm{~Hz}, 2 \mathrm{H}), 4.03(\mathrm{~s}, 3 \mathrm{H}), 3.48(\mathrm{t}$, $J=6.6 \mathrm{~Hz}, 2 \mathrm{H}) ;{ }^{13} \mathrm{C}-\mathrm{NMR}\left(\mathrm{DMSO}-d_{6}\right) \delta 146.2,145.5,144.1,137.9,128.6,127.6,124.2,123.9$ (3), 122.1 , 121.2, 118.8, 117.3, 115.7, 114.8, 56.7, 55.9, 55.2, 25.6; HRMS: calcd for $\mathrm{C}_{20} \mathrm{H}_{16} \mathrm{NO}_{4} \mathrm{Cl}[\mathrm{M}-\mathrm{Cl}]^{+}: 334.1074$, found: 334.1079 .

\subsubsection{General Procedure for the Synthesis of $13 \mathbf{a}-\mathbf{t}$}

To a stirred solution of compound 11 (361 mg, $1.0 \mathrm{mmol}, 1.0$ equiv) and $\mathrm{K}_{2} \mathrm{CO}_{3}(2.0$ equiv) in anhydrous $\mathrm{CH}_{3} \mathrm{CN}(20 \mathrm{~mL})$ were added various benzyl bromides (15.0 equiv). The reaction mixture was refluxed for 3-24 h, cooled, the mixture was filtered and the filtrate was purified by flash column chromatography on silica gel using a gradient of $\mathrm{CH}_{2} \mathrm{Cl}_{2}$ and $\mathrm{CH}_{3} \mathrm{OH}$ as eluent to obtain the compounds $12 \mathbf{a}-\mathbf{t}$. Then $12 \mathbf{a}-\mathbf{t}$ were heated at $195-210{ }^{\circ} \mathrm{C}$ in a dry oven under vacuum $(20-30 \mathrm{mmHg})$ for $40 \mathrm{~min}$ to create the crude materials, which were acidified in concentrated $\mathrm{HCl} / \mathrm{EtOH}(5: 95$ by vol.) for $10 \mathrm{~min}$. Then the mixture was evaporated under vacuum and purified by flash column chromatography on silica gel using a $\mathrm{CH}_{2} \mathrm{Cl}_{2}$ and $\mathrm{CH}_{3} \mathrm{OH}$ gradient as eluent to obtain the desired compounds $13 \mathbf{a}-\mathbf{t}$.

1,2-Methylenedioxy-8-hydroxy-9-methoxy-13-benzylcycloberberine chloride (13a): red solid; yield: 78\%; m.p.: 248-250 ${ }^{\circ} \mathrm{C} ;{ }^{1} \mathrm{H}-\mathrm{NMR}\left(\mathrm{CDCl}_{3} / \mathrm{CD}_{3} \mathrm{OD}\right) \delta 9.91(\mathrm{~s}, 1 \mathrm{H}), 8.20(\mathrm{~s}, 1 \mathrm{H}), 8.11$ (d, J = 9.0 Hz, 1H), 7.99 (d, $J=9.0 \mathrm{~Hz}, 1 \mathrm{H}), 7.39(\mathrm{~s}, 1 \mathrm{H}), 7.36-7.31(\mathrm{~m}, 2 \mathrm{H}), 7.29-7.24(\mathrm{~m}, 3 \mathrm{H}), 6.22(\mathrm{~s}, 2 \mathrm{H}), 5.14(\mathrm{t}, J=6.6 \mathrm{~Hz}, 2 \mathrm{H})$, $4.78(\mathrm{~s}, 2 \mathrm{H}), 4.11(\mathrm{~s}, 3 \mathrm{H}), 3.66(\mathrm{t}, J=6.6 \mathrm{~Hz}, 2 \mathrm{H}) ;{ }^{13} \mathrm{C}-\mathrm{NMR}\left(\mathrm{CDCl}_{3} / \mathrm{CD}_{3} \mathrm{OD}\right) \delta 148.6,147.2,146.7,143.3$, 140.5, 140.0, 129.6 (2), 129.2 (2), 128.8, 128.3, 127.1 (2), 126.8, 124.7, 123.6, 121.5, 119.4, 118.1, 116.8, 114.2, 111.3, 102.9, 57.2, 56.7, 41.1, 28.1; HRMS: calcd for $\mathrm{C}_{28} \mathrm{H}_{22} \mathrm{NO}_{4} \mathrm{Cl}[\mathrm{M}-\mathrm{Cl}]^{+}:$436.1543, found: 436.1535 .

1,2-Methylenedioxy-8-hydroxy-9-methoxy-13-p-fluorobenzylcycloberberine chloride (13b): red solid; yield: 83\%; m.p.: 203-205 ${ }^{\circ} \mathrm{C}$; ${ }^{1} \mathrm{H}-\mathrm{NMR}\left(\mathrm{CDCl}_{3} / \mathrm{CD}_{3} \mathrm{OD}\right) \delta 9.93$ (s, 1H), 8.33 (s, 1H), $8.22(\mathrm{~d}, J=9.0 \mathrm{~Hz}$, $1 \mathrm{H}), 8.04(\mathrm{~d}, J=9.0 \mathrm{~Hz}, 1 \mathrm{H}), 7.41(\mathrm{~s}, 1 \mathrm{H}), 7.30-7.24(\mathrm{~m}, 2 \mathrm{H}), 7.04-6.98(\mathrm{~m}, 2 \mathrm{H}), 6.19(\mathrm{~s}, 2 \mathrm{H}), 5.12(\mathrm{t}$, $J=6.6 \mathrm{~Hz}, 2 \mathrm{H}), 4.74(\mathrm{~s}, 2 \mathrm{H}), 4.11(\mathrm{~s}, 3 \mathrm{H}), 3.64(\mathrm{t}, J=6.7 \mathrm{~Hz}, 2 \mathrm{H}) ;{ }^{13} \mathrm{C}-\mathrm{NMR}\left(\mathrm{CDCl}_{3} / \mathrm{CD}_{3} \mathrm{OD}\right) \delta 162.8$, 149.0, 147.6, 147.2, 146.7, 143.3, 140.3, 136.9, 131.5, 131.4, 129.4, 128.7, 127.9, 125.1, 123.9, 122.2, 119.5, 118.7, 117.2, 116.1, 116.0, 114.7, 111.6, 103.4, 57.4, 57.0, 40.5, 28.3; HRMS: calcd for $\mathrm{C}_{28} \mathrm{H}_{21} \mathrm{NO}_{4} \mathrm{FCl}$ $[\mathrm{M}-\mathrm{Cl}]^{+}:$454.1449, found: 454.1447 .

1,2-Methylenedioxy-8-hydroxy-9-methoxy-13-2',4'-difluorobenzylcycloberberine chloride (13c): red solid; yield: 78\%; m.p.: $218-220{ }^{\circ} \mathrm{C} ;{ }^{1} \mathrm{H}-\mathrm{NMR}\left(\mathrm{DMSO}-d_{6}\right) \delta 11.56(\mathrm{~s}, 1 \mathrm{H}), 10.09(\mathrm{~s}, 1 \mathrm{H}), 8.54(\mathrm{~s}, 1 \mathrm{H}), 8.29$ (d, $J=9.0 \mathrm{~Hz}, 1 \mathrm{H}), 8.15(\mathrm{~d}, J=9.0 \mathrm{~Hz}, 1 \mathrm{H}), 7.56(\mathrm{~s}, 1 \mathrm{H}), 7.30-7.26(\mathrm{~m}, 1 \mathrm{H}), 7.00-6.93(\mathrm{~m}, 2 \mathrm{H}), 6.19(\mathrm{~s}, 2 \mathrm{H})$, $5.17(\mathrm{t}, J=6.6 \mathrm{~Hz}, 2 \mathrm{H}), 4.67(\mathrm{~s}, 2 \mathrm{H}), 4.07(\mathrm{~s}, 3 \mathrm{H}), 3.59(\mathrm{t}, J=6.6 \mathrm{~Hz}, 2 \mathrm{H}) ;{ }^{13} \mathrm{C}-\mathrm{NMR}\left(\mathrm{DMSO}-d_{6}\right) \delta 161.7$, 
160.1, 147.3, 147.0, 146.3, 146.2, 141.7, 136.0, 131.2, 128.6, 127.7, 127.4, 124.9, 123.7, 122.4, 122.3, 118.1, 117.6, 116.3, 114.0, 111.8, 111.0, 104.2, 102.5, 57.4, 55.4, 32.7, 26.9; HRMS: calcd for $\mathrm{C}_{28} \mathrm{H}_{20} \mathrm{NO}_{4} \mathrm{~F}_{2} \mathrm{Cl}$ $[\mathrm{M}-\mathrm{Cl}]^{+}:$472.1355, found: 472.1346 .

1,2-Methylenedioxy-8-hydroxy-9-methoxy-13-2',6'-difluorobenzylcycloberberine chloride (13d): red solid; yield: 73\%; m.p.: $214-216{ }^{\circ} \mathrm{C}$; ${ }^{1} \mathrm{H}-\mathrm{NMR}\left(\mathrm{DMSO}_{6}\right) \delta 11.57(\mathrm{~s}, 1 \mathrm{H}), 10.07(\mathrm{~s}, 1 \mathrm{H}), 8.11(\mathrm{~d}, J=9.0 \mathrm{~Hz}, 1 \mathrm{H})$, $7.90(\mathrm{~s}, 1 \mathrm{H}), 7.84(\mathrm{~d}, J=9.0 \mathrm{~Hz}, 1 \mathrm{H}), 7.60(\mathrm{~s}, 1 \mathrm{H}), 7.56-7.50(\mathrm{~m}, 1 \mathrm{H}), 7.27-7.20(\mathrm{~m}, 2 \mathrm{H}), 6.33(\mathrm{~s}, 2 \mathrm{H}), 5.15$ $(\mathrm{t}, J=6.6 \mathrm{~Hz}, 2 \mathrm{H}), 4.77(\mathrm{~s}, 2 \mathrm{H}), 4.02(\mathrm{~s}, 3 \mathrm{H}), 3.59(\mathrm{t}, J=6.6 \mathrm{~Hz}, 2 \mathrm{H}) ;{ }^{13} \mathrm{C}-\mathrm{NMR}\left(\mathrm{DMSO}-d_{6}\right) \delta 161.5(2)$, 147.5, 147.0, 146.5, 146.2, 142.1, 136.3, 130.3, 128.5, 127.7, 127.1, 125.0, 121.8, 118.7, 117.9, 117.4, 116.3, 114.3, 113.1, 112.4, 112.3, 111.1, 102.6, 57.3, 55.4, 27.6, 26.9; HRMS: calcd for $\mathrm{C}_{28} \mathrm{H}_{20} \mathrm{NO}_{4} \mathrm{~F}_{2} \mathrm{Cl}[\mathrm{M}-\mathrm{Cl}]^{+}$: 472.1355, found: 472.1342 .

1,2-Methylenedioxy-8-hydroxy-9-methoxy-13-p-chlorobenzylcycloberberine chloride (13e): red solid; yield: 88\%; m.p.: $199-201{ }^{\circ} \mathrm{C} ;{ }^{1} \mathrm{H}-\mathrm{NMR}\left(\mathrm{CDCl}_{3} / \mathrm{CD}_{3} \mathrm{OD}\right) \delta 9.93(\mathrm{~s}, 1 \mathrm{H}), 8.27(\mathrm{~s}, 1 \mathrm{H}), 8.19(\mathrm{~d}, J=8.4 \mathrm{~Hz}, 1 \mathrm{H})$, $8.02(\mathrm{~d}, J=8.4 \mathrm{~Hz}, 1 \mathrm{H}), 7.39(\mathrm{~s}, 1 \mathrm{H}), 7.29(\mathrm{~d}, J=8.4 \mathrm{~Hz}, 2 \mathrm{H}), 7.22(\mathrm{~d}, J=8.4 \mathrm{~Hz}, 2 \mathrm{H}), 6.21(\mathrm{~s}, 2 \mathrm{H}), 5.14(\mathrm{t}$, $J=6.6 \mathrm{~Hz}, 2 \mathrm{H}), 4.75(\mathrm{~s}, 2 \mathrm{H}), 4.12(\mathrm{~s}, 3 \mathrm{H}), 3.67(\mathrm{t}, J=6.6 \mathrm{~Hz}, 2 \mathrm{H}) ;{ }^{13} \mathrm{C}-\mathrm{NMR}\left(\mathrm{CDCl}_{3} / \mathrm{CD}_{3} \mathrm{OD}\right) \delta 148.6$, 147.3, 146.8, 146.1, 143.1, 139.7, 138.9, 132.9, 131.0 (2), 129.2 (2), 128.9, 128.3, 127.0, 124.9, 123.6, 121.9, 119.2, 118.2, 116.8, 114.4, 111.4, 103.0, 57.3, 56.8, 40.5, 28.1; HRMS: calcd for $\mathrm{C}_{28} \mathrm{H}_{21} \mathrm{NO}_{4} \mathrm{Cl}_{2}[\mathrm{M}-\mathrm{Cl}]^{+}$: 470.1154, found: 470.1144 .

1,2-Methylenedioxy-8-hydroxy-9-methoxy-13-p-bromobenzylcycloberberine chloride (13f): red solid; yield: 88\%; m.p.: 207-209 ${ }^{\circ} \mathrm{C} ;{ }^{1} \mathrm{H}-\mathrm{NMR}\left(\mathrm{CDCl}_{3} / \mathrm{CD}_{3} \mathrm{OD}\right) \delta 9.93(\mathrm{~s}, 1 \mathrm{H}), 8.22(\mathrm{~s}, 1 \mathrm{H}), 8.15(\mathrm{~d}, J=8.4 \mathrm{~Hz}, 1 \mathrm{H})$, $7.99(\mathrm{~d}, J=8.4 \mathrm{~Hz}, 1 \mathrm{H}), 7.44(\mathrm{~d}, J=7.8 \mathrm{~Hz}, 2 \mathrm{H}), 7.38(\mathrm{~s}, 1 \mathrm{H}), 7.15(\mathrm{~d}, J=8.4 \mathrm{~Hz}, 2 \mathrm{H}), 6.21(\mathrm{~s}, 2 \mathrm{H}), 5.15(\mathrm{t}$, $J=6.6 \mathrm{~Hz}, 2 \mathrm{H}), 4.73(\mathrm{~s}, 2 \mathrm{H}), 4.12(\mathrm{~s}, 3 \mathrm{H}), 3.68(\mathrm{t}, J=6.6 \mathrm{~Hz}, 2 \mathrm{H}) ;{ }^{13} \mathrm{C}-\mathrm{NMR}\left(\mathrm{CDCl}_{3} / \mathrm{CD}_{3} \mathrm{OD}\right) \delta 148.4$, 147.1, 146.6, 145.7, 142.9, 139.4, 139.0, 132.1 (2), 131.1 (2), 128.6, 128.0, 126.6, 124.6, 123.4, 121.6, 120.8, 119.0, 117.9, 116.5, 114.1, 111.3, 102.8, 57.2, 56.6, 40.4, 28.0; HRMS: calcd for $\mathrm{C}_{28} \mathrm{H}_{21} \mathrm{BrNO}_{4} \mathrm{Cl}[\mathrm{M}-\mathrm{Cl}]^{+}$: 514.0648, found: 514.0653 .

1,2-Methylenedioxy-8-hydroxy-9-methoxy-13-o-methylbenzylcycloberberine chloride (13g): red solid; yield: 83\%; m.p.: 203-205 ${ }^{\circ} \mathrm{C} ;{ }^{1} \mathrm{H}-\mathrm{NMR}$ (DMSO- $\left.d_{6}\right) \delta 11.54(\mathrm{~s}, 1 \mathrm{H}), 10.09(\mathrm{~s}, 1 \mathrm{H}), 8.34(\mathrm{~s}, 1 \mathrm{H}), 8.15(\mathrm{~s}, 2 \mathrm{H})$, $7.57(\mathrm{~s}, 1 \mathrm{H}), 7.29(\mathrm{~d}, J=7.8 \mathrm{~Hz}, 1 \mathrm{H}), 7.16(\mathrm{t}, J=7.2 \mathrm{~Hz}, 1 \mathrm{H}), 7.05(\mathrm{t}, J=7.2 \mathrm{~Hz}, 1 \mathrm{H}), 6.73(\mathrm{~d}, J=7.5 \mathrm{~Hz}$, $1 \mathrm{H}), 6.16(\mathrm{~s}, 2 \mathrm{H}), 5.18(\mathrm{t}, J=6.6 \mathrm{~Hz}, 2 \mathrm{H}), 4.66(\mathrm{~s}, 2 \mathrm{H}), 4.06(\mathrm{~s}, 3 \mathrm{H}), 3.34(\mathrm{~s}, 2 \mathrm{H}), 2.38(\mathrm{~s}, 3 \mathrm{H}) ;{ }^{13} \mathrm{C}-\mathrm{NMR}$ (DMSO- $d_{6}$ ) $\delta 146.8,146.2,145.8,145.7,141.4,138.2,137.2,135.8,129.9,129.5,127.9,127.7,126.9,126.1$, 125.9, 124.4, 121.8, 121.1, 118.1, 117.1, 115.8, 113.2, 110.4, 101.9, 56.8, 54.9, 37.1, 26.4, 19.2; HRMS: calcd for $\mathrm{C}_{29} \mathrm{H}_{24} \mathrm{NO}_{4} \mathrm{Cl}\left[\mathrm{M}-\mathrm{Cl}^{+}\right.$: 450.1700 , found: 450.1687 .

1,2-Methylenedioxy-8-hydroxy-9-methoxy-13-m-methylbenzylcycloberberine chloride (13h): red solid; yield: 79\%; m.p.: 203-205 ${ }^{\circ} \mathrm{C} ;{ }^{1} \mathrm{H}-\mathrm{NMR}$ (DMSO- $\left.d_{6}\right) \delta 11.52(\mathrm{~s}, 1 \mathrm{H}), 10.07(\mathrm{~s}, 1 \mathrm{H}), 8.68(\mathrm{~s}, 1 \mathrm{H}), 8.44(\mathrm{~d}, J=9.0 \mathrm{~Hz}$, $1 \mathrm{H}), 8.17(\mathrm{~d}, J=9.0 \mathrm{~Hz}, 1 \mathrm{H}), 7.55(\mathrm{~s}, 1 \mathrm{H}), 7.20-7.10(\mathrm{~m}, 2 \mathrm{H}), 7.06(\mathrm{~d}, J=7.8 \mathrm{~Hz}, 1 \mathrm{H}), 6.99(\mathrm{~d}, J=7.2 \mathrm{~Hz}$, $1 \mathrm{H}), 6.27(\mathrm{~s}, 2 \mathrm{H}), 5.15(\mathrm{t}, J=6.6 \mathrm{~Hz}, 2 \mathrm{H}), 4.68(\mathrm{~s}, 2 \mathrm{H}), 4.08(\mathrm{~s}, 3 \mathrm{H}), 3.58(\mathrm{t}, J=6.6 \mathrm{~Hz}, 2 \mathrm{H}), 2.23(\mathrm{~s}, 3 \mathrm{H})$; ${ }^{13}$ C-NMR (DMSO- $d_{6}$ ) $\delta 146.7,146.2,145.7,145.7,141.2,140.0,137.8,137.3,129.5,129.0,128.2,127.8$, 127.0, 126.7, 125.5, 124.3, 122.0, 121.8, 117.7, 117.1, 115.8, 113.7, 110.4, 101.8, 56.9, 54.9, 39.7, 26.4, 21.0; HRMS: calcd for $\mathrm{C}_{29} \mathrm{H}_{24} \mathrm{NO}_{4} \mathrm{Cl}\left[\mathrm{M}-\mathrm{Cl}^{+}\right.$: 450.1700 , found: 450.1687 .

1,2-Methylenedioxy-8-hydroxy-9-methoxy-13-p-methylbenzylcycloberberine chloride (13i): red solid; yield: 81\%; m.p.: $229-231{ }^{\circ} \mathrm{C} ;{ }^{1} \mathrm{H}-\mathrm{NMR}$ (DMSO- $\left.d_{6}\right) \delta 11.51(\mathrm{~s}, 1 \mathrm{H}), 10.06(\mathrm{~s}, 1 \mathrm{H}), 8.67(\mathrm{~s}, 1 \mathrm{H}), 8.43(\mathrm{~d}, J=9.0 \mathrm{~Hz}$, $1 \mathrm{H}), 8.16(\mathrm{~d}, J=9.0 \mathrm{~Hz}, 1 \mathrm{H}), 7.55(\mathrm{~s}, 1 \mathrm{H}), 7.17(\mathrm{~d}, J=7.8 \mathrm{~Hz}, 2 \mathrm{H}), 7.07(\mathrm{~d}, J=8.4 \mathrm{~Hz}, 2 \mathrm{H}), 6.26(\mathrm{~s}, 2 \mathrm{H}), 5.15$ $(\mathrm{t}, J=6.6 \mathrm{~Hz}, 2 \mathrm{H}), 4.66(\mathrm{~s}, 2 \mathrm{H}), 4.08(\mathrm{~s}, 3 \mathrm{H}), 3.57(\mathrm{t}, J=6.6 \mathrm{~Hz}, 2 \mathrm{H}), 2.22(\mathrm{~s}, 3 \mathrm{H}) ;{ }^{13} \mathrm{C}-\mathrm{NMR}\left(\mathrm{DMSO}-d_{6}\right) \delta$ 147.3, 146.7, 146.2, 146.2, 141.7, 138.6, 137.6, 135.5, 129.4 (2), 128.8 (2), 128.4, 127.6, 127.6, 124.8, 122.5, $122.2,118.2,117.7,116.3,114.3,110.9,102.4,57.4,55.4,39.3,27.0,21.0$; HRMS: calcd for $\mathrm{C}_{29} \mathrm{H}_{24} \mathrm{NO}_{4} \mathrm{Cl}$ $[\mathrm{M}-\mathrm{Cl}]^{+}: 450.1700$, found: 450.1704 .

1,2-Methylenedioxy-8-hydroxy-9-methoxy-13-3',5'-dimethylbenzylcycloberber ine chloride (13j): red solid; yield: $83 \%$; m.p.: $218-220{ }^{\circ} \mathrm{C} ;{ }^{1} \mathrm{H}-\mathrm{NMR}\left(\mathrm{DMSO}_{6}\right) \delta 11.48(\mathrm{~s}, 1 \mathrm{H}), 10.03(\mathrm{~s}, 1 \mathrm{H}), 8.64(\mathrm{~s}, 1 \mathrm{H}), 8.42(\mathrm{~d}$, 
$J=9.0 \mathrm{~Hz}, 1 \mathrm{H}), 8.15(\mathrm{~d}, J=9.0 \mathrm{~Hz}, 1 \mathrm{H}), 7.53(\mathrm{~s}, 1 \mathrm{H}), 6.87(\mathrm{~s}, 2 \mathrm{H}), 6.78(\mathrm{~s}, 1 \mathrm{H}), 6.25(\mathrm{~s}, 2 \mathrm{H}), 5.12(\mathrm{t}$, $J=6.6 \mathrm{~Hz}, 2 \mathrm{H}), 4.61(\mathrm{~s}, 2 \mathrm{H}), 4.06(\mathrm{~s}, 3 \mathrm{H}), 3.55(\mathrm{t}, J=6.6 \mathrm{~Hz}, 2 \mathrm{H}), 2.15(\mathrm{~s}, 6 \mathrm{H}) ;{ }^{13} \mathrm{C}-\mathrm{NMR}\left(\mathrm{DMSO}-d_{6}\right) \delta$ 146.7, 146.1, 145.7 (2), 141.2, 139.9, 137.9, 137.1, 129.5, 127.8, 127.5, 127.1, 127.0, 126.2 (2), 124.2, 122.0, 121.8, 117.7, 117.1, 115.8, 113.8, 110.4, 101.8, 56.9, 54.9, 39.5, 26.4, 20.9 (2); HRMS: calcd for $\mathrm{C}_{30} \mathrm{H}_{26} \mathrm{NO}_{4} \mathrm{Cl}$ $[\mathrm{M}-\mathrm{Cl}]^{+}:$464.1856, found: 464.1848 .

1,2-Methylenedioxy-8-hydroxy-9-methoxy-13-p-tert-butylmethylbenzylcyclo berberine chloride (13k): red solid; yield: 77\%; m.p.: $212-214{ }^{\circ} \mathrm{C} ;{ }^{1} \mathrm{H}-\mathrm{NMR}\left(\mathrm{DMSO}-\mathrm{d}_{6}\right) \delta 11.51(\mathrm{~s}, 1 \mathrm{H}), 10.06(\mathrm{~s}, 1 \mathrm{H}), 8.73(\mathrm{~s}, 1 \mathrm{H}), 8.48(\mathrm{~d}$, $J=9.0 \mathrm{~Hz}, 1 \mathrm{H}), 8.17(\mathrm{~d}, J=9.0 \mathrm{~Hz}, 1 \mathrm{H}), 7.56(\mathrm{~s}, 1 \mathrm{H}), 7.30-7.21(\mathrm{~m}, 4 \mathrm{H}), 6.29(\mathrm{~s}, 2 \mathrm{H}), 5.14(\mathrm{t}, J=6.6 \mathrm{~Hz}$, $2 \mathrm{H}), 4.68(\mathrm{~s}, 2 \mathrm{H}), 4.09(\mathrm{~s}, 3 \mathrm{H}), 3.54(\mathrm{t}, J=6.6 \mathrm{~Hz}, 2 \mathrm{H}), 1.21(\mathrm{~s}, 9 \mathrm{H}) ;{ }^{13} \mathrm{C}-\mathrm{NMR}$ (DMSO-d $\left.d_{6}\right) \delta 148.3,146.7$, 146.1, 145.7, 141.1, 138.1, 137.2, 132.5, 128.0 (2), 127.8, 127.2, 127.0, 125.0 (2), 124.2, 122.0, 121.8, 117.6, $117.2,115.8,113.8,110.3,101.8,56.9,54.9,48.5,38.5,31.0$ (3), 26.4; HRMS: calcd for $\mathrm{C}_{32} \mathrm{H}_{30} \mathrm{NO}_{4} \mathrm{Cl}$ $[\mathrm{M}-\mathrm{Cl}]^{+}:$492.2169, found: 492.2158 .

1,2-Methylenedioxy-8-hydroxy-9-methoxy-13-p-trifluoromethoxybenzylcyclo berberine chloride (131): red solid; yield: 77\%; m.p.: $185-187^{\circ} \mathrm{C} ;{ }^{1} \mathrm{H}-\mathrm{NMR}\left(\mathrm{DMSO}-\mathrm{d}_{6}\right) \delta 11.53(\mathrm{~s}, 1 \mathrm{H}), 10.08(\mathrm{~s}, 1 \mathrm{H}), 8.78(\mathrm{~s}, 1 \mathrm{H}), 8.48(\mathrm{~d}$, $J=9.0 \mathrm{~Hz}, 1 \mathrm{H}), 8.17(\mathrm{~d}, J=9.0 \mathrm{~Hz}, 1 \mathrm{H}), 7.56(\mathrm{~s}, 1 \mathrm{H}), 7.42(\mathrm{~d}, J=7.8 \mathrm{~Hz}, 2 \mathrm{H}), 7.26(\mathrm{~d}, J=8.4 \mathrm{~Hz}, 2 \mathrm{H}), 6.26$ $(\mathrm{s}, 2 \mathrm{H}), 5.15(\mathrm{t}, J=6.6 \mathrm{~Hz}, 2 \mathrm{H}), 4.73(\mathrm{~s}, 2 \mathrm{H}), 4.09(\mathrm{~s}, 3 \mathrm{H}), 3.58(\mathrm{t}, J=6.6 \mathrm{~Hz}, 2 \mathrm{H}) ;{ }^{13} \mathrm{C}-\mathrm{NMR}\left(\mathrm{DMSO}-d_{6}\right) \delta$ 146.8, 146.6, 146.3, 145.7 (2), 141.0, 139.8, 137.1, 130.1 (2), 129.5, 127.9, 127.2, 127.0, 124.3, 122.2, 122.0, 120.9 (2), 117.4, 117.2, 115.8, 113.8, 110.4, 101.9, 56.9, 54.9, 38.4, 26.4; HRMS: calcd for $\mathrm{C}_{29} \mathrm{H}_{21} \mathrm{NO}_{5} \mathrm{~F}_{3} \mathrm{Cl}$ $[\mathrm{M}-\mathrm{Cl}]^{+}:$520.1366, found: 520.1349 .

1,2-Methylenedioxy-8-hydroxy-9-methoxy-13-o-cyanbenzylcycloberberine chloride (13m): red solid; yield: 83\%; m.p.: 209-211 ${ }^{\circ} \mathrm{C} ;{ }^{1} \mathrm{H}-\mathrm{NMR}\left(\mathrm{CDCl}_{3} / \mathrm{CD}_{3} \mathrm{OD}\right) \delta 9.96(\mathrm{~s}, 1 \mathrm{H}), 8.27(\mathrm{~s}, 1 \mathrm{H}), 8.14(\mathrm{~d}, J=9.0 \mathrm{~Hz}, 1 \mathrm{H})$, $8.01(\mathrm{~d}, J=9.0 \mathrm{~Hz}, 1 \mathrm{H}), 7.80(\mathrm{dd}, J=7.8,1.2 \mathrm{~Hz}, 1 \mathrm{H}), 7.54(\mathrm{td}, J=7.8,1.2 \mathrm{~Hz}, 1 \mathrm{H}), 7.44(\mathrm{t}, J=7.8 \mathrm{~Hz}, 1 \mathrm{H})$, $7.40(\mathrm{~s}, 1 \mathrm{H}), 7.19(\mathrm{~d}, J=7.8 \mathrm{~Hz}, 1 \mathrm{H}), 6.19(\mathrm{~s}, 2 \mathrm{H}), 5.16(\mathrm{t}, J=6.6 \mathrm{~Hz}, 2 \mathrm{H}), 4.98(\mathrm{~s}, 2 \mathrm{H}), 4.12(\mathrm{~s}, 3 \mathrm{H}), 3.68(\mathrm{t}$, $J=6.6 \mathrm{~Hz}, 2 \mathrm{H}) ;{ }^{13} \mathrm{C}-\mathrm{NMR}\left(\mathrm{CDCl}_{3} / \mathrm{CD}_{3} \mathrm{OD}\right) \delta 148.6,147.4,146.8,146.3,144.0,142.9,137.5,133.9,133.8$, $130.1,129.0,128.2,128.0,127.0,124.9,123.4,122.2,118.9,118.6,118.1,116.7,114.2,113.2,111.5,103.0$, 57.2, 56.7, 39.5, 28.0; HRMS: calcd for $\mathrm{C}_{29} \mathrm{H}_{21} \mathrm{~N}_{2} \mathrm{O}_{4} \mathrm{Cl}[\mathrm{M}-\mathrm{Cl}]^{+}$: 461.1496, found: 461.1502.

1,2-Methylenedioxy-8-hydroxy-9-dimethoxy-13-m-cyanbenzylcycloberberine chloride (13n): red solid; yield: 87\%; m.p.: $189-191{ }^{\circ} \mathrm{C} ;{ }^{1} \mathrm{H}-\mathrm{NMR}\left(\mathrm{CD}_{3} \mathrm{OD}\right) \delta 9.95(\mathrm{~s}, 1 \mathrm{H}), 8.50(\mathrm{~s}, 1 \mathrm{H}), 8.33(\mathrm{~d}, J=9.0 \mathrm{~Hz}, 1 \mathrm{H}), 8.07(\mathrm{~d}$, $J=9.0 \mathrm{~Hz}, 1 \mathrm{H}), 7.58(\mathrm{td}, J=9.0,1.2 \mathrm{~Hz}, 2 \mathrm{H}), 7.55(\mathrm{~s}, 1 \mathrm{H}), 7.45(\mathrm{t}, J=7.8 \mathrm{~Hz}, 1 \mathrm{H}), 7.42(\mathrm{~s}, 1 \mathrm{H}), 6.15(\mathrm{~s}$, $2 \mathrm{H}), 5.13(\mathrm{t}, J=6.6 \mathrm{~Hz}, 2 \mathrm{H}), 4.81(\mathrm{~s}, 2 \mathrm{H}), 4.11(\mathrm{~s}, 3 \mathrm{H}), 3.64(\mathrm{t}, J=6.6 \mathrm{~Hz}, 2 \mathrm{H}),{ }^{13} \mathrm{C}-\mathrm{NMR}\left(\mathrm{CD}_{3} \mathrm{OD}\right) \delta 151.0$, 148.4, 146.9, 145.8, 142.5, 141.3, 138.2, 133.8, 132.3, 130.6, 129.8, 129.2, 128.5, 126.9, 126.3, 123.2, 121.7, 120.7, 119.0, 118.7, 118.5, 117.5, 112.6, 111.4, 102.5, 57.2, 56.8, 40.3, 27.6; HRMS: calcd for $\mathrm{C}_{29} \mathrm{H}_{21} \mathrm{~N}_{2} \mathrm{O}_{4} \mathrm{Cl}$ $[\mathrm{M}-\mathrm{Cl}]^{+}:$461.1496, found: 461.1495 .

1,2-Methylenedioxy-8-hydroxy-9-dimethoxy-13-p-cyanbenzylcycloberberine chloride (13o): red solid; yield: 83\%; m.p.:197-199 ${ }^{\circ} \mathrm{C} ;{ }^{1} \mathrm{H}-\mathrm{NMR}\left(\mathrm{DMSO}_{-} \mathrm{d}_{6}\right) \delta 11.54(\mathrm{~s}, 1 \mathrm{H}), 10.09(\mathrm{~s}, 1 \mathrm{H}), 8.78(\mathrm{~s}, 1 \mathrm{H}), 8.46(\mathrm{~d}, J=9.0 \mathrm{~Hz}$, $1 \mathrm{H}), 8.16(\mathrm{~d}, J=9.0 \mathrm{~Hz}, 1 \mathrm{H}), 7.74(\mathrm{~d}, J=8.4 \mathrm{~Hz}, 2 \mathrm{H}), 7.55(\mathrm{~s}, 1 \mathrm{H}), 7.46(\mathrm{~d}, J=7.8 \mathrm{~Hz}, 2 \mathrm{H}), 6.21(\mathrm{~s}, 2 \mathrm{H})$, $5.16(\mathrm{t}, J=6.6 \mathrm{~Hz}, 2 \mathrm{H}), 4.78(\mathrm{~s}, 2 \mathrm{H}), 4.09(\mathrm{~s}, 3 \mathrm{H}), 3.58(\mathrm{t}, J=6.6 \mathrm{~Hz}, 2 \mathrm{H}) ;{ }^{13} \mathrm{C}-\mathrm{NMR}$ (DMSO- $\left.d_{6}\right) \delta 146.8$, 146.4, 146.2, 145.8, 145.7, 140.9, 136.0, 132.2 (2), 129.31 (2), 128.0, 127.2, 127.0, 124.3, 122.5, 121.9, 118.8, $117.4,117.1,115.8,113.8,110.5,108.9,101.9,56.9,54.9,39.2,26.4$; HRMS: calcd for $\mathrm{C}_{29} \mathrm{H}_{21} \mathrm{~N}_{2} \mathrm{O}_{4} \mathrm{Cl}[\mathrm{M}-$ $\mathrm{Cl}]^{+}:$461.1496, found: 461.1500 .

1,2-Methylenedioxy-8-hydroxy-9-methoxy-13-o-nitrobenzylcycloberberine chloride (13p): red solid; yield: 82\%; m.p.: $199-201{ }^{\circ} \mathrm{C} ;{ }^{1} \mathrm{H}-\mathrm{NMR}$ (DMSO- $\left.d_{6}\right) \delta 11.57(\mathrm{~s}, 1 \mathrm{H}), 10.11(\mathrm{~s}, 1 \mathrm{H}), 8.69(\mathrm{~s}, 1 \mathrm{H}), 8.35(\mathrm{~d}, J=9.0 \mathrm{~Hz}$, $1 \mathrm{H}), 8.18(\mathrm{~d}, J=9.0 \mathrm{~Hz}, 1 \mathrm{H}), 8.05(\mathrm{dd}, J=7.8,1.2 \mathrm{~Hz}, 1 \mathrm{H}), 7.56-7.46(\mathrm{~m}, 3 \mathrm{H}), 7.07(\mathrm{dd}, J=7.8,1.2 \mathrm{~Hz}$, $1 \mathrm{H}), 6.04(\mathrm{~s}, 2 \mathrm{H}), 5.17(\mathrm{t}, J=6.6 \mathrm{~Hz}, 2 \mathrm{H}), 4.88(\mathrm{~s}, 2 \mathrm{H}), 4.08(\mathrm{~s}, 3 \mathrm{H}), 3.58(\mathrm{t}, J=6.6 \mathrm{~Hz}, 2 \mathrm{H}) ;{ }^{13} \mathrm{C}-\mathrm{NMR}$ (DMSO-d $d_{6}$ ) $\delta 149.7,147.3,147.1,146.4,146.3,141.4,135.9,134.8,133.7,131.0,130.1,128.6,128.1,127.8$, $127.5,124.9,123.1,122.3,118.0,117.6,116.4,114.2,111.0,102.3,57.4,55.4,36.7,26.9$; HRMS: calcd for $\mathrm{C}_{28} \mathrm{H}_{21} \mathrm{~N}_{2} \mathrm{O}_{6} \mathrm{Cl}[\mathrm{M}-\mathrm{Cl}]^{+}:$481.1394, found: 481.1381 . 
1,2-Methylenedioxy-8-hydroxy-9-methoxy-13-m-nitrobenzylcycloberberine chloride (13q): red solid; yield: 89\%; m.p.: $186-188^{\circ} \mathrm{C}^{1}{ }^{1} \mathrm{H}-\mathrm{NMR}\left(\mathrm{CDCl}_{3} / \mathrm{CD}_{3} \mathrm{OD}\right) \delta 9.97(\mathrm{~s}, 1 \mathrm{H}), 8.47(\mathrm{~s}, 1 \mathrm{H}), 8.31(\mathrm{~d}, J=8.4 \mathrm{~Hz}, 1 \mathrm{H})$, $8.12-8.08(\mathrm{~m}, 2 \mathrm{H}), 8.05(\mathrm{~d}, J=9.0 \mathrm{~Hz}, 1 \mathrm{H}), 7.69(\mathrm{~d}, J=7.8 \mathrm{~Hz}, 1 \mathrm{H}), 7.54(\mathrm{t}, J=8.4 \mathrm{~Hz}, 1 \mathrm{H}), 7.40(\mathrm{~s}$, $1 \mathrm{H}), 6.20(\mathrm{~s}, 2 \mathrm{H}), 5.16(\mathrm{t}, J=6.6 \mathrm{~Hz}, 2 \mathrm{H}), 4.90(\mathrm{~s}, 2 \mathrm{H}), 4.13(\mathrm{~s}, 3 \mathrm{H}), 3.68(\mathrm{t}, J=6.6 \mathrm{~Hz}, 2 \mathrm{H}) ;{ }^{13} \mathrm{C}-\mathrm{NMR}$ $\left(\mathrm{CDCl}_{3} / \mathrm{CD}_{3} \mathrm{OD}\right) \delta 149.2,148.7,147.5,146.9,146.4,142.8(2), 138.2,135.9,130.2,129.2,128.4,127.2,125.0$, 124.0, 123.7, 122.7, 122.2, 119.0, 118.3, 116.9, 114.5, 111.6, 103.0, 57.3, 56.8, 40.7, 28.1; HRMS: calcd for $\mathrm{C}_{28} \mathrm{H}_{21} \mathrm{~N}_{2} \mathrm{O}_{6} \mathrm{Cl}[\mathrm{M}-\mathrm{Cl}]^{+}:$481.1394, found: 481.1392 .

1,2-Methylenedioxy-8-hydroxy-9-methoxy-13-p-nitrobenzylcycloberberine chloride (13r): red solid; yield: 85\%; m.p.: $186-188{ }^{\circ} \mathrm{C} ;{ }^{1} \mathrm{H}-\mathrm{NMR}\left(\mathrm{CDCl}_{3} / \mathrm{CD}_{3} \mathrm{OD}\right) \delta 9.98(\mathrm{~s}, 1 \mathrm{H}), 8.49(\mathrm{~s}, 1 \mathrm{H}), 8.33(\mathrm{~d}, J=9.0 \mathrm{~Hz}, 1 \mathrm{H})$, $8.16(\mathrm{~s}, 1 \mathrm{H}), 8.15(\mathrm{~s}, 1 \mathrm{H}), 8.07(\mathrm{~d}, J=9.0 \mathrm{~Hz}, 1 \mathrm{H}), 7.47(\mathrm{~d}, J=8.4 \mathrm{~Hz}, 2 \mathrm{H}), 7.41(\mathrm{~s}, 1 \mathrm{H}), 6.17(\mathrm{~s}, 2 \mathrm{H})$, $5.15(\mathrm{t}, J=6.6 \mathrm{~Hz}, 2 \mathrm{H}), 4.91(\mathrm{~s}, 2 \mathrm{H}), 4.13(\mathrm{~s}, 3 \mathrm{H}), 3.66(\mathrm{t}, J=6.6 \mathrm{~Hz}, 2 \mathrm{H}) ;{ }^{13} \mathrm{C}-\mathrm{NMR}\left(\mathrm{CDCl}_{3} / \mathrm{CD}_{3} \mathrm{OD}\right) \delta$ 148.9, 148.8, 147.6 (2), 147.1, 146.7, 143.0, 138.2, 130.4 (2), 129.4, 128.6, 127.6, 125.1, 124.4 (2), 123.8, 123.0, 119.2, 118.5, 117.1, 114.7, 111.7, 103.2, 57.4, 56.9, 41.1, 28.2; HRMS: calcd for $\mathrm{C}_{28} \mathrm{H}_{21} \mathrm{~N}_{2} \mathrm{O}_{6} \mathrm{Cl}[\mathrm{M}-\mathrm{Cl}]^{+}$: 481.1394, found: 481.1390 .

1,2-Methylenedioxy-8-hydroxy-9-methoxy-13-1'-phenylethylcycloberberine chloride (13s): orange solid; yield: 82\%; m.p.: $213-215^{\circ} \mathrm{C} ;{ }^{1} \mathrm{H}-\mathrm{NMR}$ (DMSO-d 6 ) $\delta 11.53(\mathrm{~s}, 1 \mathrm{H}), 10.07(\mathrm{~s}, 1 \mathrm{H}), 8.49(\mathrm{~s}, 1 \mathrm{H}), 8.43$ (d, J = $9.0 \mathrm{~Hz}$, $1 \mathrm{H}), 8.13(\mathrm{~d}, J=9.0 \mathrm{~Hz}, 1 \mathrm{H}), 7.56(\mathrm{~s}, 1 \mathrm{H}), 7.41-7.37(\mathrm{~m}, 2 \mathrm{H}), 7.30(\mathrm{t}, J=7.8 \mathrm{~Hz}, 2 \mathrm{H}), 7.19(\mathrm{tt}, J=7.2$, $1.2 \mathrm{~Hz}, 1 \mathrm{H}), 6.35(\mathrm{~s}, 1 \mathrm{H}), 6.23-6.20(\mathrm{~m}, 1 \mathrm{H}), 5.48(\mathrm{q}, J=6.6 \mathrm{~Hz}, 1 \mathrm{H}), 5.20-5.06(\mathrm{~m}, 2 \mathrm{H}), 4.08(\mathrm{~s}, 3 \mathrm{H}), 3.57$ $(\mathrm{t}, J=6.6 \mathrm{~Hz}, 2 \mathrm{H}), 1.87(\mathrm{~d}, J=7.2 \mathrm{~Hz}, 3 \mathrm{H}) ;{ }^{13} \mathrm{C}-\mathrm{NMR}\left(\mathrm{DMSO}-d_{6}\right) \delta 147.4,146.8,146.3,146.2,145.7,144.0$, 141.6, 128.8 (2), 128.3, 128.2 (2), 127.8, 127.5, 126.7, 124.7, 122.2, 119.0, 118.2, 117.7, 116.3, 114.3, 111.0, 102.2, 57.4, 55.4, 41.0, 27.0, 22.7; HRMS: calcd for $\mathrm{C}_{29} \mathrm{H}_{24} \mathrm{NO}_{4} \mathrm{Cl}[\mathrm{M}-\mathrm{Cl}]^{+}: 450.1700$, found: 450.1706 .

1,2-Methylenedioxy-8-hydroxy-9-methoxy-13-2'-methoxy-2'-oxo-1'-phenylethylcycloberberine chloride (13t): orange solid; yield: $84 \%$; m.p.: $173-175{ }^{\circ} \mathrm{C} ;{ }^{1} \mathrm{H}-\mathrm{NMR}$ (DMSO- $\left.d_{6}\right) \delta 11.62(\mathrm{~s}, 1 \mathrm{H}), 10.10(\mathrm{~s}, 1 \mathrm{H}), 8.14(\mathrm{~d}$, $J=9.0 \mathrm{~Hz}, 1 \mathrm{H}), 7.97(\mathrm{~s}, 1 \mathrm{H}), 7.76(\mathrm{~s}, 1 \mathrm{H}), 7.61(\mathrm{~s}, 1 \mathrm{H}), 7.53-7.41(\mathrm{~m}, 5 \mathrm{H}), 6.35(\mathrm{~s}, 1 \mathrm{H}), 6.32(\mathrm{~s}, 1 \mathrm{H}), 6.24$ (s, 1H), 5.20-5.09 (m, 2H), $4.04(\mathrm{~s}, 3 \mathrm{H}), 3.73(\mathrm{~s}, 3 \mathrm{H}), 3.63-3.57(\mathrm{~m}, 2 \mathrm{H}) ;{ }^{13} \mathrm{C}-\mathrm{NMR}$ (DMSO-d 6 ) $\delta 171.9$, 147.0, 146.9, 146.0, 145.7, 141.0, 137.0, 136.2, 129.5, 129.1 (2), 128.9 (2), 128.1, 127.7, 127.4, 126.7, 124.6, 120.9, 117.6, 117.0, 115.8, 112.3, 110.6, 102.1, 56.8, 54.8, 54.1, 52.4, 26.4; HRMS: calcd for $\mathrm{C}_{30} \mathrm{H}_{24} \mathrm{NO}_{6} \mathrm{Cl}$ $[\mathrm{M}-\mathrm{Cl}]^{+}:$494.1598, found: 494.1591 .

\subsubsection{General Procedure for the Synthesis of $15 \mathbf{a}-\mathbf{c}$}

To a stirred solution of intermediate 11 [15] (361 mg, $1.0 \mathrm{mmol}, 1.0$ equiv) in $80 \% \mathrm{EtOH}(20 \mathrm{~mL})$, various aliphatic aldehydes (5.0 equiv) and HOAc $(4 \mathrm{~mL})$ were added. The reaction mixture was heated to reflux for $8 \mathrm{~h}$. The solvent was removed by evaporation to afford a red oil. The red oil was acidified by $2 \% \mathrm{HCl}$, stirred at room temperature for $0.5 \mathrm{~h}$. The solvent was removed and the residue was purified by flash chromatography over silica gel using $\mathrm{CH}_{2} \mathrm{Cl}_{2} / \mathrm{CH}_{3} \mathrm{OH}$ (5:1) as eluent to obtain the intermediate compounds $14 a-c$. Next $14 a-c$ were heated at $195-210{ }^{\circ} \mathrm{C}$ in a dry oven under vacuum (20-30 $\mathrm{mmHg}$ ) for $40 \mathrm{~min}$ to create the crude materials, to were acidified in concentrated $\mathrm{HCl} / \mathrm{EtOH}$ (5:95 by vol.) for $10 \mathrm{~min}$. Then the mixture was evaporated under vacuum and purified by flash column chromatography on silica gel using a gradient of $\mathrm{CH}_{2} \mathrm{Cl}_{2}$ and $\mathrm{CH}_{3} \mathrm{OH}$ as eluent to obtain the desired compounds 15a-c.

1,2-Methylenedioxy-8-hydroxy-9-methoxy-13-ethylcycloberberine chloride (15a): orange solid; yield: 82\%; m.p.: $166-168^{\circ} \mathrm{C}^{1}{ }^{1} \mathrm{H}-\mathrm{NMR}$ (DMSO- $\left.d_{6}\right) \delta 11.49(\mathrm{~s}, 1 \mathrm{H}), 10.05(\mathrm{~s}, 1 \mathrm{H}), 8.54(\mathrm{~s}, 1 \mathrm{H}), 8.49(\mathrm{~d}, J=9.0 \mathrm{~Hz}, 1 \mathrm{H})$, $8.12(\mathrm{~d}, J=9.0 \mathrm{~Hz}, 1 \mathrm{H}), 7.55(\mathrm{~s}, 1 \mathrm{H}), 6.34(\mathrm{~s}, 2 \mathrm{H}), 5.14(\mathrm{t}, J=6.6 \mathrm{~Hz}, 2 \mathrm{H}), 4.08(\mathrm{~s}, 3 \mathrm{H}), 3.57(\mathrm{t}, J=6.6 \mathrm{~Hz}$, $2 \mathrm{H}), 3.30(\mathrm{q}, J=7.2 \mathrm{~Hz}, 2 \mathrm{H}), 1.36(\mathrm{t}, J=7.2 \mathrm{~Hz}, 3 \mathrm{H}) ;{ }^{13} \mathrm{C}-\mathrm{NMR}\left(\mathrm{DMSO}-d_{6}\right) \delta 146.8,145.9,145.7(2), 141.5$, 141.2, 127.6, 127.1 (2), 124.2, 122.2, 119.8, 117.5, 117.1, 115.9, 114.1, 110.3, 102.0, 57.0, 55.0, 28.0, 26.6, 16.1; HRMS: calcd for $\mathrm{C}_{23} \mathrm{H}_{20} \mathrm{NO}_{4} \mathrm{Cl}[\mathrm{M}-\mathrm{Cl}]^{+}: 374.1387$, found: 374.1396 .

1,2-Methylenedioxy-8-hydroxy-9-methoxy-13-propylcycloberberine chloride (15b): orange solid; yield: 85\%; m.p.: $165-167^{\circ} \mathrm{C} ;{ }^{1} \mathrm{H}-\mathrm{NMR}\left(\mathrm{DMSO}-d_{6}\right) \delta 11.49(\mathrm{~s}, 1 \mathrm{H}), 10.04(\mathrm{~s}, 1 \mathrm{H}), 8.58(\mathrm{~s}, 1 \mathrm{H}), 8.53(\mathrm{~d}, J=9.0 \mathrm{~Hz}, 1 \mathrm{H})$, 
$8.15(\mathrm{~d}, J=9.0 \mathrm{~Hz}, 1 \mathrm{H}), 7.55(\mathrm{~s}, 1 \mathrm{H}), 6.34(\mathrm{~s}, 2 \mathrm{H}), 5.15(\mathrm{t}, J=6.6 \mathrm{~Hz}, 2 \mathrm{H}), 4.09(\mathrm{~s}, 3 \mathrm{H}), 3.58(\mathrm{t}, J=6.6 \mathrm{~Hz}$, $2 \mathrm{H}), 3.28(\mathrm{t}, J=7.8 \mathrm{~Hz}, 2 \mathrm{H}), 1.80-1.72(\mathrm{~m}, 2 \mathrm{H}), 1.02(\mathrm{t}, J=7.2 \mathrm{~Hz}, 3 \mathrm{H}) ;{ }^{13} \mathrm{C}-\mathrm{NMR}$ (DMSO- $\left.d_{6}\right) \delta 146.6$, 145.8, 145.6 (2), 141.2, 139.7, 127.6, 127.1, 127.0, 124.1, 122.0, 120.5, 117.6, 117.1, 115.8, 114.0, 110.2, 101.9, 56.9, 54.9, 36.5, 26.4, 24.3, 13.72; HRMS: calcd for $\mathrm{C}_{24} \mathrm{H}_{22} \mathrm{NO}_{4} \mathrm{Cl}[\mathrm{M}-\mathrm{Cl}]^{+}: 388.1543$, found: 388.1553.

1,2-Methylenedioxy-8-hydroxy-9-methoxy-13-butylcycloberberine chloride (15c): orange solid; yield: 88\%; m.p.: $162-164{ }^{\circ} \mathrm{C} ;{ }^{1} \mathrm{H}-\mathrm{NMR}\left(\mathrm{DMSO}-d_{6}\right) \delta 11.45(\mathrm{~s}, 1 \mathrm{H}), 10.02(\mathrm{~s}, 1 \mathrm{H}), 8.55(\mathrm{~s}, 1 \mathrm{H}), 8.50(\mathrm{~d}, J=9.0 \mathrm{~Hz}, 1 \mathrm{H})$, $8.12(\mathrm{~d}, J=9.0 \mathrm{~Hz}, 1 \mathrm{H}), 7.53(\mathrm{~s}, 1 \mathrm{H}), 6.31(\mathrm{~s}, 2 \mathrm{H}), 5.12(\mathrm{t}, J=6.6 \mathrm{~Hz}, 2 \mathrm{H}), 4.06(\mathrm{~s}, 3 \mathrm{H}), 3.55(\mathrm{t}, J=6.6 \mathrm{~Hz}$, $2 \mathrm{H}), 3.27(\mathrm{t}, J=7.8 \mathrm{~Hz}, 2 \mathrm{H}), 1.68(\mathrm{t}, J=7.8 \mathrm{~Hz}, 2 \mathrm{H}), 1.46-1.38(\mathrm{~m}, 2 \mathrm{H}), 0.93(\mathrm{t}, J=7.2 \mathrm{~Hz}, 3 \mathrm{H}) ;{ }^{13} \mathrm{C}-\mathrm{NMR}$ $\left(\right.$ DMSO- $\left._{6}\right) \delta 146.7,145.8,145.6$ (2), 141.2, 140.0, 127.6, 127.1, 127.0, 124.1, 122.1, 120.4, 117.6, 117.1, $115.8,114.0,110.2,101.9,56.9,54.9,34.3,33.3,25.4,22.0,13.7$; HRMS: calcd for $\mathrm{C}_{25} \mathrm{H}_{24} \mathrm{NO}_{4} \mathrm{Cl}[\mathrm{M}-\mathrm{Cl}]^{+}$: 402.1700, found: 402.1692 .

\subsection{Antimicrobial Assay}

Minimum inhibitory concentrations (MICs) of the target compounds were determined by using the agar dilution assay at various concentrations of $64,32,16,8.0,4.0,2.0,1.0,0.5,0.25,0.125,0.06$ and $0.03 \mathrm{mg} / \mathrm{mL}$ described by the Clinical Laboratory Standards Institute [17]. Bacterial strains were purchased from the ATCC collection or isolated from Chinese hospitals. The medium was Mueller-Hinton agar, and the inoculum was $10^{4}$ colony forming units (cfu)/spot. Culture plates were incubated at $35^{\circ} \mathrm{C}$ for $18 \mathrm{~h}$, and MICs were defined as the lowest concentrations that prevented visible growth of the bacteria.

\subsection{Time-kill Curves of $\mathbf{1 5 a}$}

Kill kinetics of 15a was determined by time-kill experiments for MRSA strain (clinical isolate MRSA 18-4) according to the method described by Verma et al. with slight modifications [25]. An overnight culture was diluted with CAMH broth in a total volume of $30 \mathrm{~mL}$ containing an inoculum of $2 \times 10^{6} \mathrm{CFU} / \mathrm{mL}$ in a $250 \mathrm{~mL}$ flask for 18-4. Distilled water or 15a was added to yield concentrations of $0 \times, 1 / 2 \times, 2 \times$ and $8 \times$ MIC in the broth at standard inocula. Viability counts were performed at $0,2,4,8$ and $12 \mathrm{~h}$ of incubation at $37^{\circ} \mathrm{C}$ by plating $0.1 \mathrm{~mL}$ undiluted and 10-fold serial diluted samples onto TSA plates in duplicate. Drug carryover effect was eliminated by saline and agar dilution. The experiments were performed three times on different days and the results were presented as mean and standard deviation.

\subsection{Stability Assay of Key Compound in Liver Microsomes}

The assay was performed with liver microsomes from CD-1 mouse, SD rat and human. Microsomes in $100 \mathrm{mM}$ potassium phosphate buffer $\left(0.5 \mathrm{mg} / \mathrm{mL}\right.$ microsomal protein), cofactor $\mathrm{MgCl}_{2}$ $(10 \mathrm{mM})$, tested compound $\left(1 \mu \mathrm{M}\right.$, cosolvent $\left.(0.01 \% \mathrm{DMSO}), 0.99 \% \mathrm{CH}_{3} \mathrm{OH}\right)$, and then NADPH $(1 \mathrm{mM})$ at $37^{\circ} \mathrm{C}$ for $60 \mathrm{~min}$. The reaction can be started by the addition of liver microsomes or the tested compound or NADPH. Aliquots were sampled at 0, 5, 10, 20, 30 and 60 min incubation, and enzymatic reaction was stopped by protein precipitation in cold acetonitrile including $100 \mathrm{ng} / \mathrm{mL}$ tolbutamide and $100 \mathrm{ng} / \mathrm{mL}$ labetalol as internal standard. After centrifugation, samples were then analyzed by LC/MS/MS [26].

\subsection{Stability Assay of Key Compound in SD Rat Whole Blood}

Fresh blood was collected on the day of experiment from SD rats and pre-warmed in a water bath at $37^{\circ} \mathrm{C} .10 \mathrm{mM}$ test compound or Ems stock solutions were prepared in DMSO, and then diluted with $45 \% \mathrm{MeOH} / \mathrm{H}_{2} \mathrm{O}$ to achieve $100 \mu \mathrm{M}$ dosing solutions. Each dosing solution $(2 \mu \mathrm{L})$ was incubated with $98 \mu \mathrm{L}$ of blank blood at $37^{\circ} \mathrm{C}$ in water bath for $0,0.5,1,3,7$ and $24 \mathrm{~h}$, respectively. At the end of incubation, for each sample, $100 \mu \mathrm{L}$ water and $800 \mu \mathrm{L}$ of stop solution $(200 \mathrm{ng} / \mathrm{mL}$ tolbutamide plus $20 \mathrm{ng} / \mathrm{mL}$ buspirone in ACN) were immediately added to to precipitate protein and centrifuge at 
4,000 rpm for $20 \mathrm{~min}$. An aliquot of supernatant $(100 \mu \mathrm{L})$ was then extracted, mixed with $200 \mu \mathrm{L} \mathrm{H}_{2} \mathrm{O}$ and then shook at $800 \mathrm{rpm}$ for about $10 \mathrm{~min}$ before submitting to LC-MS/MS analysis. The experiment was repeated two times [18].

\subsection{Acute Toxicity Assay}

Female Kunming mice with weight of $20.0( \pm 1.0 \mathrm{~g})$ were fed with regular rodent chow and housed in an air conditioned room. The mice were randomly divided into different groups with 6 mice each. Each compound was given intravenously in a single-dosing experiment at 40,60, or $80 \mathrm{mg} \cdot \mathrm{kg}^{-1}$ $\left(\mathrm{ddH}_{2} \mathrm{O}\right.$ as control), respectively. The mice were closely monitored for 7 days. Body weight as well as survival was monitored [18].

\subsection{Enzymatic Assay}

The gyrase supercoling assay kit and topo IV decatenation kit were the tools for detection the target compound inhibited the activity of DNA gyrase and topo IV from MRSA (both kits obtained from Inspiralis, Norwich, United Kingdom). Briefly, supercoiled pBR322 plasmid DNA (0.5 mg) and 13a of varying concentrations $(2.5-100 \mu \mathrm{g} / \mathrm{mL})$ were incubated with $1 \mathrm{U}$ gyrase in the dedicated supercoiling assay buffer supplied by the manufacturer. Reactions were carried out at $37^{\circ} \mathrm{C}$ for $30 \mathrm{~min}$ and then terminated by the addition of equal volume of STEB buffer $(40 \%$ sucrose, $100 \mathrm{mM}$ Tris- $\mathrm{HCl}$ pH 7.5, $1 \mathrm{mM}$ EDTA, $0.5 \mathrm{mg} / \mathrm{ml}$ bromophenol blue) and chloroform/isoamyl alcohol. Samples were vortexed, centrifuged and run through a $15 \mathrm{~cm} 1 \%$ agarose gel in TAE buffer (40 mM Tris-acetate, $2 \mathrm{mM}$ EDTA) for $3 \mathrm{~h}$ at $50 \mathrm{~V}$. Gels were stained with ethidium bromide and visualized under UV light. The decatenation assay was performed using MRSA topo IV decatenation kit. The operational approach was similar to above. Bands were visualized by UV light and photographed [27].

\subsection{Molecular Docking Assay}

The topo IV crystal structure in complex with kibdelomycin (PDB code 4URL, resolution: $2.29 \AA$ ) was selected as the template to generate the binding modes [24]. Discovery Studio 4.5 was used to create structures of the ligands and to perform energy minimization [16]. The LibDock software was employed. Before docking, protein structure and ligands were processed [28]. In the course of protein preparation, ligands and water molecules were removed from the structure. The docking conformation with the highest docking score was finally chosen to analyze the receptor ligand interaction in the Discovery Studio 4.5 software.

\section{Conclusions}

A total of 25 new derivatives of $\mathbf{1}$ were designed, synthesized and evaluated for their anti-Gram-positive microbes activities with $\mathbf{1}$ as the lead. SAR studies revealed that introducing a small-sized substituent at the 13-position might be beneficial for activity. Part of them showed good activities against MRSA and VISA. Compound 15a bearing a 13-ethyl group exhibited the most potent antibacterial activities, with MIC values of $0.25-0.5 \mu \mathrm{g} / \mathrm{mL}$, superior to those of the lead 1. Time-kill curve analysis of 15a further confirmed its potential bactericidal activity. Meanwhile, compound 15a displayed high liver microsomal metabolic stability and reasonable whole blood stability. It also showed a good in vivo safety profile with an $\mathrm{LD}_{50}$ value over $65.6 \mathrm{mg} \cdot \mathrm{kg}^{-1}$ in mice via the intravenous route. A preliminary mechanism study showed that compound 15a could inhibit topo IV activity through binding with the active site of kibdelomycin, a different mechanism of action from the quinolone antibiotics currently used in hospitals. Taken together, these results provide powerful information for developing these compounds into promising anti-MRSA candidates with novel chemical scaffolds and a specific biological mechanism of action, and compound 15a has been chosen for further investigation. 
Supplementary Materials: The following are available online at http:/ / www.mdpi.com/1420-3049/24/5/984/s1, the ${ }^{1} \mathrm{H}-\mathrm{NMR},{ }^{13} \mathrm{C}-\mathrm{NMR}$ and HRMS data of compound 15a.

Author Contributions: Y.-S.Y., W.W. and S.T. performed part of synthetic experiments and wrote the paper, X.-X.H. and J.P. performed the biological assay, D.-Q.S. conceived and designed the chemistry experiments, X.-F.Y. conceived and designed the biology experiments, T.-Y.F. and Y.-X.W. designed the target compounds and chemistry experiments.

Funding: This work was supported by the National Natural Science Foundation of China (81621064 and 81361138020), Beijing Natural Science Foundation (7172136), and the CAMS Innovation Fund for Medical Sciences (2017-12M-1-012).

Acknowledgments: The authors thank center for analysis and testing of Institute of Materia Medica and Institute of Medicinal Biotechnology, Chinese Academy of Medical Sciences for their contributions to the determination of HR-MS, ${ }^{1} \mathrm{H}-\mathrm{NMR}$, and ${ }^{13} \mathrm{C}-\mathrm{NMR}$.

Conflicts of Interest: The authors declare no conflict of interest.

\section{References and Notes}

1. Antibiotic Resistance: The Global Threat (U.S.); Centers for Disease Control and Prevention: Atlanta, GA, USA. Available online: http:/ / stacks.cdc.gov/view/cdc/31340 (accessed on 27 February 2015).

2. Marr, A.K.; Gooderham, W.J.; Hancock, R.E. Antibacterial peptides for therapeutic use: Obstacles and realistic outlook. Curr. Opin. Pharmacol. 2006, 6, 468-472. [CrossRef] [PubMed]

3. WHO. Antimicrobial Resistance: Global Report on Surveillance; World Health Organization: Geneva, Switzerland, 2014.

4. Filice, G.A.; Nyman, J.A.; Lexau, C.; Lees, C.H.; Bockstedt, L.A.; ComoSabetti, K.; Lesher, L.J.; Lynfield, R. Excess costs and utilization associated with methicillin resistance for patients with Staphylococcus aureus infection. Infect. Control Hosp. Epidemiol. 2010, 31, 365-373. [CrossRef] [PubMed]

5. Walsh, C.T.; Fischbach, M.A. Squashing superbugs-The race for new antibiotics. Sci. Am. 2009, 301, 44-51. [CrossRef] [PubMed]

6. Hiramatsu, K.; Hanaki, H.; Ino, T.; Yabuta, K.; Oquri, T.; Tenover, F.C. Methicillin-resistant Staphylococcus aureus clinical strain with reduced vancomycin susceptibility. J. Antimicrob. Chemother. 1997, 40, 135-136. [CrossRef] [PubMed]

7. Hiramatsu, K.; Aritaka, N.; Hanaki, H.; Kawasaki, S.; Hosoda, Y.; Hori, S.; Fukuchi, Y.; Kobayashi, I. Dissemination in Japanese hospitals of strains of Staphylococcus aureus heterogeneously resistant to vancomycin. Lancet 1997, 350, 1670-1673. [CrossRef]

8. Auckland, C.; Teare, L.; Cooke, F.; Kaufmann, M.E.; Warner, M.; Jones, G.; Bamford, K.; Ayles, H.; Johnson, A.P. Linezolid-resistant enterococci: Report of the first isolates in the United Kingdom. J. Antimicrob. Chemother. 2002, 50, 743-746. [CrossRef] [PubMed]

9. Marty, F.M.; Yeh, W.W.; Wennersten, C.B.; Venkataraman, L.; Albano, E.; Alyea, E.P.; Gold, H.S.; Baden, L.R.; Pillai, S.K. Emergence of a clinical daptomycin-resistant Staphylococcus aureus isolate during treatment of methicillin-resistant Staphylococcus aureus bacteremia and osteomyelitis. J. Clin. Microbiol. 2006, 44, 595-597. [CrossRef] [PubMed]

10. Chan, L.C.; Basuino, L.; Diep, B.; Hamilton, S.; Chatterjee, C.C.; Chambers, H.F. Ceftobiprole- and ceftaroline-resistant methicillin-resistant Staphylococcus aureus. Antimicrob. Agents Chemother. 2015, 59, 2960-2963. [CrossRef] [PubMed]

11. Tacconelli, E.; Carrara, E.; Savoldi, A.; Harbarth, S.; Mendelson, M.; Monnet, D.L.; Pulcini, C.; Kahlmeter, G.; Kluytmans, J.; Carmeli, Y.; et al. Discovery, research, and development of new antibiotics: The WHO priority list of antibiotic-resistant bacteria and tuberculosis. Lancet Infect. Dis. 2018, 18, 318-327. [CrossRef]

12. Liu, Y.X.; Xiao, C.L.; Wang, Y.X.; Li, Y.H.; Yang, Y.H.; Li, Y.B.; Bi, C.W.; Gao, L.M.; Jiang, J.D.; Song, D.Q. Synthesis, structure-activity relationship and in vitro anti-mycobacterial evaluation of 13-n-octylberberine derivatives. Eur. J. Med. Chem. 2012, 52, 151-158. [CrossRef] [PubMed]

13. Fu, H.G.; Hu, X.X.; Li, C.R.; Li, Y.H.; Wang, Y.X.; Jiang, J.D.; Bi, C.W.; Tang, S.; You, X.F.; Song, D.Q. Design, synthesis and biological evaluation of monobactams as antibacterial agents against gram-negative bacteria. Eur. J. Med. Chem. 2016, 110, 151-163. [CrossRef] [PubMed] 
14. Li, Y.B.; Zhao, W.L.; Wang, Y.X.; Zhang, C.X.; Jiang, J.D.; Bi, C.W.; Tang, S.; Chen, R.X.; Shao, R.G.; Song, D.Q. Discovery, synthesis and biological evaluation of cycloprotoberberine derivatives as potential antitumor agents. Eur. J. Med. Chem. 2013, 68, 463-472. [CrossRef] [PubMed]

15. Fan, T.Y.; Hu, X.X.; Tang, S.; Liu, X.J.; Wang, Y.X.; Deng, H.B.; You, X.F.; Jiang, J.D.; Li, Y.H.; Song, D.Q. Discovery and development of 8-substituted cycloberberine derivatives as novel antibacterial agents against MRSA. ACS Med. Chem. Lett. 2018, 9, 484-489. [CrossRef] [PubMed]

16. Fan, T.Y.; Wang, Y.X.; Tang, S.; Hu, X.X.; Zeng, Q.X.; Pang, J.; Yang, Y.S.; You, X.F.; Song, D.Q. Synthesis and antibacterial evaluation of 13-substituted cycloberberine derivatives as a novel class of anti-MRSA agents. Eur. J. Med. Chem. 2018, 157, 877-886. [CrossRef] [PubMed]

17. National Committee for Clinical Laboratory Standards. Methods for dilution antimicrobial susceptibility tests for bacteria that grow aerobically; Clinical and Laboratory Standards Institute: Wayne, PA, USA, 2018; pp. M07-M10.

18. Lu, X.; Yang, X.Y.; Li, X.; Lu, Y.; Ren, Z.T.; Zhao, L.Y.; Hu, X.X.; Jiang, J.D.; You, X.F. In vitro activity of sodium new houttuyfonate alone and in combination with oxacillin or netilmicin against methicillin-resistant Staphylococcus aureus. PLoS ONE 2013, 8, e68053. [CrossRef] [PubMed]

19. Plech, T.; Kaproń, B.; Paneth, A.; Kosikowska, U.; Malm, A.; Strzelczyk, A.; Stączek, P.; Świątek, Ł.; Rajtar, B.; Polz-Dacewicz, M. Search for factors affecting antibacterial activity and toxicity of 1,2,4-triazole-ciprofloxacin hybrids. Eur. J. Med. Chem. 2015, 97, 94-103. [CrossRef] [PubMed]

20. O'Dowd, H.; Dean, E.; Shannon, K.R.; Chandupatla, V.D.; Juntyma, J.E.; Ye, Z.Q.; Jones, S.M.; O’Brien, C.F.; Nicolau, D.P.; Tessier, P.R.; et al. Discovery and characterization of a water-soluble prodrug of a dual inhibitor of bacterial DNA gyrase and topoisomerase IV. ACS Med. Chem. Lett. 2015, 6, 822-826. [CrossRef] [PubMed]

21. Badshah, S.L.; Ullah, A. New developments in non-quinolone-based antibiotics for the inhibition of bacterial gyrase and topoisomerase IV. Eur. J. Med. Chem. 2018, 152, 393-400. [CrossRef] [PubMed]

22. Champoux, J. DNA topoisomerases: Structure, function and mechanism. J. Annu. Rev. Biochem. 2001, 70, 369-413. [CrossRef] [PubMed]

23. Phillips, J.W.; Goetz, M.A.; Smith, S.K.; Zink, D.L.; Polishook, J.; Onishi, R.; Salowe, S.; Wiltsie, J.; Allocco, J.; Sigmund, J.; et al. Discovery of kibdelomycin, a potent new class of bacterial type II topoisomerase inhibitor by chemical-genetic profiling in Staphylococcus aureus. Chem. Biol. 2011, 18, 955-965. [CrossRef] [PubMed]

24. Lu, J.; Patel, S.; Sharma, N.; Soisson, S.M.; Kishii, R.; Takei, M.; Fukuda, Y.; Lumb, K.J.; Singh, S.B. Structures of kibdelomycin bound to Staphylococcus aureus GyrB and ParE showed a novel U-shaped binding mode. ACS Chem. Biol. 2014, 9, 2023-2031. [CrossRef] [PubMed]

25. Verma, P. Methods for determining bactericidal activity and antimicrobial interactions synergy testing, time-kill curves, and population analysis. In Antimicrobial Susceptibility Testing Protocols; Schwalbe, R., Steele-Moore, L., Goodwin, A.C., Eds.; CRC Press: Roca Raton, FL, USA, 2017; pp. 275-298.

26. Wang, B.; Wang, K.; Meng, P.; Hu, Y.; Yang, F.; Liu, K.; Lei, Z.; Chen, B.; Tian, Y. Design, synthesis, and evaluation of carboxyl-modified oseltamivir derivatives with improved lipophilicity as neuraminidase inhibitors. Bioorg. Med. Chem. Lett. 2018, 28, 3477-3482. [CrossRef] [PubMed]

27. Bielenica, A.; Stefańska, J.; Stępień, K.; Napiórkowska, A.; Augustynowicz-Kopeć, E.; Sanna, G.; Madeddu, S.; Boi, S.; Giliberti, G.; Wrzosek, M.; et al. Synthesis, cytotoxicity and antimicrobial activity of thiourea derivatives incorporating 3-(trifluoromethyl)phenyl moiety. Eur. J. Med. Chem. 2015, 101, 111-125. [CrossRef] [PubMed]

28. Sharma, N.; Sharma, M.; Shakeel, E.; Jamal, Q.M.; Kamal, M.A.; Sayeed, U.; Khan, M.K.; Siddiqui, M.H.; Arif, J.M.; Akhtar, S. Molecular interaction and computational analytical studies of pinocembrin for its antiangiogenic potential targeting VEGFR-2: A persuader of metastasis. Med. Chem. 2018, 14, 626-640. [CrossRef] [PubMed]

Sample Availability: Samples of the compounds 6, 10, 13a-t and 15a-c are available from the authors. 